\title{
EL DOMINIO DEL MONASTERIO DE SAN MILLÁN DE LA COGOLLA, BADARÁN EN LA EDAD MODERNA
}

Santiago Ibáñez Rodríguez ${ }^{1}$

No cabe duda de que la fundación y rápida consolidación del Monasterio de San Millán de la Cogolla durante la Edad Media marcó la organización espacial de buena parte del norte peninsular de igual manera que lo hizo en el valle del río Cárdenas donde se asentaba y en la vida diaria de sus habitantes. En efecto, la trayectoria del cenobio emilianense estuvo íntimamente ligada a la Reconquista y la repoblación, a la ocupación y ordenación del espacio conquistado a los árabes y a la consolidación de las fronteras entre los propios reinos cristianos. El dominio del monasterio fue en esa época constantemente favorecido con privilegios y donaciones de monarcas y gentes principales, alcanzando así su mayor esplendor en el medievo y, sin malograrlo, continuó manteniéndolo a lo largo de la Edad Moderna hasta su clausura en 1836. A hora bien, durante esta última edad, iniciada a finales del siglo XVI, su poder se recortó. De su maridaje con los reyes y señores quedó poco y todo la pompa y boato de antaño quedó reducida a un típico señorío monástico de carácter rural: mantenimiento de la jurisdicción sobre algunos lugares, cobro de derechos jurisdiccionales de renta antigua y, sobre todo, propiedad de bienes rústicos, urbanos y muchos monopolios de producción².

1. Universiad de La Rioja, santiago.ibanez@dchs.unirioja.es.

2. Al inicio de la Edad Moderna, el abad de San Millán, conde de Pazuengos, marqués de Óllora y señor de las baronías de Villanueva, era también señor de las villas y lugares de Arce, Badarán, Camprovín, Cárdenas, Cihuri, Fonzaleche, Ledesma, Pazuengos, Ventosa, Villarejo y Villaverde en La Rioja; Espinosa del Monte, Ezquerra, Miñón y La Zarzosa, San Miguel de Pedroso, Vallarta Quintana en Burgos. En un inventario del siglo XVII se añaden a las anteriores Altable, en Burgos, y Bolívar, en Álava. En el siglo XVIII el abad tan sólo era señor del lugar de Cihuri, de San Miguel del Pedroso, Pazuengos con sus aldeas Óllora y Villanueva, y de las granjas de San Martín de Soto y la Esclavitud. 
El hecho de que el Monasterio de San Millán ya no tuviese la impronta del pasado no quiere decir que el cenobio fuese más laxo con sus vasallos a lo largo de la Edad Moderna, lo que ocurrirá es que allí donde pudo mantener el señorío lo hará con fuerza, y con saña en ocasiones, pero sobre todo llevará a cabo un control de sus súbditos, ahora mitad vasallos, mitad renteros, mitad feligreses, a través de la propiedad de la tierra y el control espiritual. Sin duda el monasterio aumentó su patrimonio rústico y urbano considerablemente en estos siglos, pero ahora los vecinos de las aldeas pertenecientes a su dominio encontrarán fórmulas hasta entonces impensables para librarse del vasallaje del monasterio, nos referimos a que podrán y se atreverán a comprar su señorío y a pleitear en las Chancillerías y ante los Consejos para defender sus intereses. Todos estos aspectos son los que se pueden seguir en el caso práctico del estudio de la villa de Badarán, una de sus más importantes administraciones abaciales; para su mejor comprensión se divide el artículo en una parte dedicada a la jurisdicción civil del monasterio sobre la villa, otra sobre la jurisdicción eclesiástica, una tercera sobre el control económico y por último hablaremos sobre la administración de toda la hacienda.

El Abad del Monasterio de San Millán de la Cogolla era el señor de Badarán y lo seguirá siendo hasta 1579, después mantendrá derechos jurisdiccionales. Aún siendo señor, la jurisdicción que ejerció sobre esta villa durante la Edad Moderna no fue plena. En efecto, el Duque de Nájera había logrado poseer el derecho de nombrar Alcalde Mayor en Badarán. Esta circunstancia no nos debe extrañar, la superposición de intereses, de señores y de justicias era habitual y consustancial a la época. Como se decía a mediados del siglo XVI, el monasterio tenía jurisdicción civil y el duque la criminal ${ }^{3}$. Pero ni siquiera esta expresión limita con claridad las competencias entre ambos señores a la hora de ejercer la justicia y otros derechos en Badarán. Como vamos a ver, la jurisdicción civil y criminal, alta y baja, también es atribución del Monasterio de San Millán. Se comprenderá que, puesto que los derechos de unos y otros se entrecruzaban, la posición destacada del Duque de Nájera provocó constantes intromisiones jurisdiccionales en Badarán a lo largo del siglo XVI.

Los derechos del Monasterio de San Millán sobre Badarán y su tierra eran anteriores a 1326 y quedaron ratificados en esa fecha al constituirse la nueva villa fruto de la unión de Villorquito, Terrero, Villagonzalo y Badarán. Se desconoce desde cuándo tuvo el ducado de Nájera el derecho de nombrar Alcalde Mayor. Parece probable que obtendría tal facultad en la segunda mitad del siglo XV o primeras décadas del siglo XVI tras la constitución del ducado, gracias a su estrecha vinculación con los Reyes Católicos, cuando las reformas emprendidas por el cardenal Cisneros afectaron a los benedictinos y a San

3. AGS, DC, legajo 47, folio 31. El corregidor de Logroño sobre la información pedida sobre los monasterios de la ciudad y su jurisdicción para proceder a la venta de señorío, 1553. 
Millán pidiéndoles mayor observancia de la regla 0 tras la fuerte represión que siguió al levantamiento comunero ${ }^{5}$ en la zona de Nájera con numerosos juicios y ejecución de sentencias capitales en un ambiente de completa condescendencia de Carlos V con su buen vasallo, el Señor de Nájera, que estaba pacificándole los reinos.

Un señorío es el dominio territorial en el que su titular dispone, en mayor o menor medida, de patrimonio, rentas y jurisdicción. Posee bienes pero su condición no es de mero propietario, si no la de señor, que comprendía el ejercicio del poder político, incluidas funciones de administración, justicia y hacienda. Durante la Edad Moderna el feudalismo, en el sentido estricto, no existe puesto que ha perdido buena parte de sus elementos políticos, pero mantiene los derivados de la jurisdicción que implican vasallaje.

En Badarán nos encontramos con un señorío abadengo, puesto que era el Abad del Monasterio de San Millán de la Cogolla el que ejercía la jurisdicción. Junto al monasterio, el Duque de Nájera mantenía cierta jurisdicción, la derivada de poseer el derecho de nombrar Alcalde Mayor. El dominio del monasterio al inicio de la Edad Moderna sobre el municipio era triple: a través de la jurisdicción, por medio del control espiritual y como mayor propietario del municipio. Más a estos derechos habría que añadir otros menos tangibles y que se derivaban del ejercicio de funciones que sólo podía ofrecer el monasterio, como por ejemplo la difusión cultural o la utilización de los preparados de la renombrada botica emilianense.

\section{Señorío y jurisdicción.}

El señorío jurisdiccional del Abad del Monasterio de San Millán de la Cogolla sobre Badarán se concretaba, en expresión de la época, en:

“la jurisdicción civil y criminal, alta y baja, mero mixto imperio, con las penas de cámara y sangre, calumnias y visitas del Concejo, y el yantar, y las décimas de exención, y las dos cargas de leña que el monasterio tenía cada semana en dicha villa, y así mismo las escribanías públicas y del Concejo, y otras cualesquiera

4. García O ro, J., 1971, Cisneros y la reforma del clero español en tiempo de los Reyes Católicos, Madrid, CSIC.

5. Hubo levantamientos a favor de los comuneros o de carácter antiseñorial en los lugares de Huércanos, Uruñuela, Matute, Camprovín, Pedroso, Anguiano y otros. Gutiérrez N ieto, J.I., 1973, Las Comunidades como movimiento antiseñorial. La formación del bando realista en la guerra civil castellana de 1520-1521, Barcelona. También Goicolea Julián, F.J., 2000, «La ciudad de Nájera en el tránsito de la edad media a la moderna: el concejo, el señor y la sociedad política ciudadana», H ispania 205, pp. 425-452. 
rentas anejas y pertenecientes a la dicha jurisdicción y el derecho de elegir alcaldes de la Hermandad y otros oficiales que acostumbraba nombrar por el ejercicio de dicha jurisdicción"6.

Como se dice en otro lugar, era del abad todas “las demás rentas y aprovechamientos al servicio de la dicha villa y vasallaje pertenecientes en cualquier manera, desde la hoja del monte hasta la piedra del río"7.

Tal como se expone en lo citado, el Abad y Monasterio de San Millán reciben de Badarán y sus vecinos vasallaje y ostenta prerrogativas jurídicoadministrativas. Con la expresión "jurisdicción civil y criminal, alta y baja, mero mixto imperio" los contemporáneos utilizaban tres locuciones con significado sinónimo: la potestad de ejercer la justicia civil y criminal y la autoridad para castigar con penas tanto pecuniarias como "imponer en el cuerpo pena grave y capital a los hombres facinerosos". El abad de San Millán ejercía en Badarán la justicia, era el juez en todos los asuntos civiles y criminales, podía imponer penas a los delincuentes con conocimiento de causa, incluso penas de cámara y sangre y además recibía una parte de las multas aplicadas. Para hacer valer su justicia hacía uso de los Alcaldes O rdinarios, cuyo nombramiento estaba en sus manos. Estos oficiales no tenían porque tener preparación jurídica y eran meros instrumentos del abad.

Hemos dicho que el abad de San Millán tenía plena potestad de ejercer la justicia en Badarán, pero este derecho tenía un límite, el impuesto por las competencias del Alcalde Mayor nombrado por el Duque de Nájera. Ya hemos hablado de las dificultades de definir tales funciones, pero es fácil entender que aunque el Alcalde Mayor podía dar sentencias no acordes a las del abad de San Millán, era más sencilla la connivencia entre el Abad y el Duque que entre los vasallos y alguno de sus señores.

El abad de San Millán tuvo también como suyas hasta el siglo XVI casi todas las potestades gubernativas sobre la villa de Badarán, prerrogativas por medio de las cuales se imponía en el municipio y controlaba a las autoridades locales y con ello el funcionamiento administrativo del concejo e incluso la vida social del municipio. El abad designaba a todo el personal necesario para "el buen gobierno de la villa": alcaldes de hermandad, regidores, guardas, alguaciles, procurador del común, personal al cargo de los propios, etc. También designaba a quienes ocupaban importantes puestos como los de las escribanías y fieles de fechos.

O tro de los derechos que existían sobre Badarán era el que obligaba a los vecinos a entregar al Monasterio de San M illán dos cargas de leña a la semana. Esta facultad se redondeaba con el "derecho del monasterio a disfrutar como los vecinos, la corta de leña en los montes y dehesa de dicha villa y de gozar

6. AHN, Clero, leg. 3065.

7. AHPLo, Catastro, caja 114, "Certificación de la jurisdicción y señorío en cuyos derechos se incorporó la villa de Badarán". 
con sus ganados los aprovechamientos de hierbas y grama de igual conformidad"8. Más el cenobio tenía el derecho de caza y pesca en el municipio y su jurisdicción aunque para estas fechas ejercido con bastante relajación. Como signo de respeto y consideración los de Badarán debían satisfacer el yantar, la obligación de sustentar con pan y alojamiento al abad cuando transitaba por el municipio o visitaba la villa.

Por último y no menos importante, el abad de San Millán tenía sobre Badarán la prerrogativa de hacer residencia a los oficiales salientes de su cargo y de fiscalizar las cuentas municipales, era encargado de celebrar la visita: comprobación periódica de la conducta de sus subordinados y de tomar las cuentas de sus ejercicios al frente de cargo público, pudiendo imponerles multas si se apreciase delito en el desempeño de su empleo.

Aunque el Concejo y Vecinos de Badarán lograrán incorporarse al realengo a comienzos del siglo XVII, el Monasterio de San Millán de la Cogolla mantendrá durante los siglos siguientes muchos de sus derechos jurisdiccionales sobre la villa. Perderá el señorío propiamente dicho, pero seguirá recibiendo derechos señoriales. Esta circunstancia no es nada excepcional. En La Rioja a mediados del siglo XVIII tan sólo trece localidades escapaban totalmente del control señorial ${ }^{9}$, el resto o eran de señorío 0 , como Badarán, seguían pagando facultades y derechos que antaño implicaron dominio o eran reminiscencia de señorío aún siendo ahora villas de realengo.

El Concejo de Badarán manifestó a mediados del siglo XVIII que los derechos que se hallaban impuestos sobre la villa, y que observamos reflejaban cierto grado de señorío, eran la pecha, la castillería, la martiniega, la polla de la botera o fumera y el yantar. Todos estas cargas debían entregarse anualmente al Monasterio de San Millán y éste las consideraba, como era natural, inextinguibles. De ninguna manera se podía permitir el cenobio una disminución o supresión, fuesen cuales fueren las razones porque ello implicaría a la larga su pérdida total.

Ciertamente estos impuestos eran muy importantes, pero el monasterio no disponía de los títulos de propiedad de los mismos ni podía dar cuanta de sus orígenes, era la costumbre y las facultades con las que se había arrogado los que le daban la propiedad pero no documento alguno, como quedó demostrado a mediados del siglo XVIII:

"De todos estos derechos, Pecha, Castillería, Martiniega, Polla de la Boteja, Yantarejano, no ha presentado dicho monasterio los títulos de pertenencia sin embargo de haber sido interpelado por medio de su apoderado y administrador". ${ }^{10}$

8. AH N, Clero, leg. 3065.

9. Ibáñez Rodríguez, S. et. al. (1996), Los señoríos en La Rioja en el siglo XVIII. Logroño, p. 74. 10. AHPLo, Catastro, respuestas particulares. 
Veamos con detalle cada uno de los derechos del Monasterio de San Millán impuestos sobre Badarán. La pecha la pagaban "los vecinos y forasteros eclesiásticos y seculares, nobles y del estado general", es decir todos los vecinos del municipio. La pecha era un tributo de reconocimiento de señorío y se le pagaba al señor territorial por razón de los bienes o haciendas. La cantidad que debía ser satisfecha por este tributo era de 112 fanegas de pan mixto hacia 1580 y estaba fijada a mediados del siglo XVIII en 56 fanegas y 3 celemines de trigo y otras 56 fanegas y 3 celemines de cebada, más 170 cántaras de vino con la condición de que si no podían entregar esta cantidad de vino por no haberla en el municipio, se abonasen "por ellas veinte fanegas de trigo y otras tantas de cebada anualmente"11. El trueque de grano a cambio de vino se logró en 1729.

La obligación que tuvieron los vecinos de Badarán de pagar la castillería y el yantar al monasterio hasta que desapareció en el siglo XIX son dos claros ejemplos del antiguo señorío y, en el caso del yantar, incluso observamos cómo lo satisfacían los moradores de la villa a pesar de haber sido uno de los derechos que desaparecieron al convertirse el pueblo al realengo. Tal era el poder del cenobio sobre Badarán y sus habitantes que logró seguir imponiendo derechos que sus habitantes habían comprado y no tenían obligación de pagar. La castillería, en su origen, era un canon por la protección que los moradores de un lugar recibían de un castillo o fortaleza, en este caso del Monasterio de San Millán. El yantar, que ya hemos visto más arriba, consistía en la manutención y el agasajo del abad y su séquito siempre que transite o visite la villa y concejo de Badarán, pagando los gastos de su alimentación y habitación. En definitiva, el yantar y la castillería son derechos simbólicos del acatamiento al señor. Tanto por la castillería como por el yantar se pagaba una cantidad fija, por el primer impuesto 15 fanegas de trigo y 15 fanegas de cebada, por el segundo, 7,5 reales $^{12}$. Estos impuestos eran tan viejos y denostosos que al final del Antiguo Régimen, a comienzos del siglo XIX, los vecinos los satisfacían malintencionadamente, entregando grano de muy mala calidad ${ }^{13}$.

Así es, el Monasterio de San Millán ya había tenido sus más y sus menos con los vecinos de Badarán para cobrar la pecha y castillería. Las desavenencias versaban sobre la obligación de satisfacer los impuestos, la cuantía de los mismos y la calidad del grano con el que se pagaba. U nos y otros alcanzaron acuerdos en 1681 y en 1729, pero a finales del siglo XVIII seguían peleando por los modos de entregar el grano y su calidad.

Según Salvador de Moxó, la presencia en épocas tardías de tributos como la martiniega informa de la existencia de un señorío solariego en el sentido de

11. AGS, EH, 150-39, años 1579-1584; y AHPLo, Catastro, caja 114 para el año 1751.

12. En 1586 decía el Concejo y Vecinos de Badarán que pagaban 30 fanegas de pan mixto por Castillería y Martiniega. AGS, EH, 150-39.

13. Archivo de la Chancillería de Valladolid, Ejecutorias, leg. 3772, "Contra los vecinos de Badarán sobre la calidad del grano de las castillerías, 1804". 
la existencia de vinculación explícita del territorio con su titular ${ }^{14}$. Ya incluso para el siglo XV la martiniega había perdido su carácter territorial para adoptar rasgos típicamente jurisdiccionales, para acabar con el tiempo una mera reminiscencia del antiguo señorío. Una gran parte de los señores en La Rioja percibía ingresos en concepto de martiniega, frecuentemente en pagos en metálico, aunque también existe la modalidad del pago en especie. La villa de Badarán pagaba al M onasterio de San Millán 35 reales y 10 maravedís en concepto de martiniega.

El último pago que satisfacía el Concejo y Vecinos de Badarán al Monasterio de San Millán era el de la polla de la botera o boteja, según los casos. A este impuesto con una denominación tan particular que se satisfacía en Badarán y en otras villas del entorno como Cordovín o Ledesma, se le conocía comunmente como fumera. En esencia era un derecho sobre los hogares habitados o fuegos (por también se le denomina derecho del humo), es decir, un impuesto que pagaba cada vecino por cada casa habitada. En Badarán se llamaba polla de la botera por ser en pollas, gallinas o capones, la especie en la que se pagaba. El impuesto no lo satisfacían todos los vecinos de Badarán, tan sólo los del Estado Llano, quedando excluidos los nobles y clérigos. En conjunto, se pagaba por este impuesto 150 reales a mediados del siglo XVIII.

Aunque cada uno de los impuestos explicados hasta ahora sumaban una cantidad determinada y particular, todos ellos eran pagados de forma comunitaria. La villa de Badarán se hacía cargo de todos en sus cuentas anuales, recaudaba el dinero entre los vecinos y después se lo hacía llegar al monasterio. El Concejo o ayuntamiento, por tanto, era el intermediario entre los vecinos y el señor abad y era el responsable del cumplimiento de pago y de la recaudación. En ocasiones se prorrateaba el impuesto entre los habitantes del municipio, en otras se distinguía el pago según la riqueza del vecino o su condición (pertenencia a uno u otro estamento social o según el estado civil) y, en un tercer caso, el Común pagaba por todos con lo que le rentaba sus propios.

\section{Jurisdicción eclesiástica y espiritual.}

En una fecha tan tardía como 1805 la visita del abad de San Millán a su parroquia de Badarán mantenía la misma monotonía que desde hacía siglos:

"Visita de la Iglesia Parroquial Monasterial de la Villa de Badarán. Año de mil ochocientos y cinco. En la villa de Badarán a veintisiete días del mes de enero del año de mil ochocientos y cinco el Reverendísimo fray Rafael Pontella Abad de San Millán, Capellán de Su Majestad, Juez Privativo, Superior Ordinario en toda la Abadía que es vere nullius dioecesis, con propio, distinto y separado territorio,

14. Moxó, S. de., Los señoríos. Estudio metodológico. Actas de las I Jornadas de Metodología A plicada a las Ciencias Históricas. II: Historia M edieval. Santiago de Compostela 1975, 167-168. 
predicador general de la Religión de San Benito, habiendo resultado visitar la Iglesia Parroquial Monasterial de Santa María de la villa de Badarán, Ilegó su Reverendísima acompañado del padre fray Joaquín Octavio, de la Justicia, Regimiento de la villa y de mi el Notario de Visita con repique de campanas a la puerta de la iglesia, en donde halló revestido con capa a D on Francisco U ruñuela, teniente cura de ella. Vistiose su Reverendísima las Insignias Pontificales, adoró la Cruz, puso incienso, esparció el agua bendita, fue incensado, entró en la iglesia con el cántico acostumbrado, y dichos los versos y oración que prescribe el ritual se retiró al sitial. Comenzose la misa que celebró dicho teniente y al ofertorio de ella mandó a mí el Notario leyese y notificase el Edicto General de Visita, luego dijo su Reverendísima una platica doctrinal y concluida la misa echó la Bendición Solemne al pueblo, visitó el Santísimo Sacramento, Pila Bautismal y Sagrados O leos, se cantaron tres responsos por las ánimas del Purgatorio, se visitaron los altares, vanos y ornamentos sagrados; y hallándose todo con aseo, y limpieza, así se quedó la visita hasta sus resultas" ${ }^{\prime 2}$.

El Abad del Monasterio de San Millán de la Cogolla visitaba la iglesia de Badarán porque era una sus múltiples parroquias monasteriales. A comienzos del siglo XVII eran parroquias propias, sufragáneas y plenamente unidas a la matriz de San Millán, más de cien iglesias y ermitas. Un importante número de ellas habían sido en el pasado iglesias y monasterios, con sus cotos y dezmatorios, y ahora las más eran ermitas y muchas derruidas. Sólo los grandes monasterios disponían de iglesias bajo su jurisdicción. A medias del siglo XVIII le pertenecía al Monasterio de Cañas la iglesia de Hormilleja, al Monasterio de San Prudencio las iglesias de Lagunilla de Jubera y Villanueva de San Prudencio; al de Nájera las de Arenzana de Arriba, Bezares, Cirueña, Santa Coloma, Sojuela y Ventosa; al de San Miguel del M onte el Barrio Bajero de Galbárruli; al de San Millán de la Cogolla las iglesias de Badarán, Camprovín, Cárdenas, Cordovín, Ledesma, San Millán, Villarejo, Villaverde de Rioja y Cihuri.

El abad de San Millán era en todas sus parroquias, y por tanto en la de Badarán, "vere nullius dioecesis" (o "nullios dioecesis" o sólo "nullios"), es decir, con autoridad similar a la episcopal. Sus atribuciones y competencias eran las mismas que las de un prelado en su diócesis: la obligación moral y material de cuidar de las observaciones eclesiásticas en el territorio que estaba bajo su mando. El abad se comportaba como un obispo diocesano y gobernaba como él en su territorio, con potestad eclesiástica suprema pudiendo convocar sínodos, proveer a los servidores o curas de las parroquias, nombrar ecónomos, conceder dimisorias (permitir recibir de otro obispo las sagradas órdenes), reservarse la absolución de censuras o irregularidades en el fuero penitencial o absolver de los casos reservados por la Santa Sede. Tenía por tanto competencias eclesiásticas y materiales y estaba facultado para resolver en asuntos jurídicos de carácter eclesiástico sucedidos dentro de su dominio. Muchos de los deberes del abad, como nullios, se ponían en práctica en la visita pastoral a las parroquias a su cargo.

15. Archivo Parroquial de Badarán (APB), Libro de cuentas de la Iglesia Parroquial (17161805).Visita del año 1805. 
La visita tenía como finalidad la vigilancia y la inspección administrativa. El abad de San Millán, o el vicario designado por él, se interesaba por los individuos que tenían a su cargo y por los bienes materiales de los que se disponía para su sustento y para el culto. Se preocupaba del estado físico de los templos, de las rentas y su administración, revisaba las cuentas, comprobaba la pulcritud de los utensilios litúrgicos, vigilaba los ornamentos de culto, revisaba la situación de las propiedades, de las tierras, los censos, los inmuebles, los hórreos, etc. La visita también se detenía en la conducta de las personas. El visitador tomaba nota de los eclesiásticos y laicos al servicio de la Iglesia, se fijaba en su vestuario y en su comportamiento, en el grado con el que cumplían los deberes clericales los unos y cómo prestan sus servicios en el culto los otros; conversaba sobre el grado moral y el conocimiento de los principios elementales de la religión; reprendía y corregía eventuales irregularidades, escándalos o conductas desviadas; se preocupaba por que todos sus parroquianos recibiesen cura de almas, conociesen la palabra de Dios y asistiesen a los oficios.

La visita, en suma, abarcaba un sin fin de aspectos que iban desde lo estrictamente teológico a la simple curiosidad humana y servía al abad para conocer todos los pormenores de sus parroquias, de sus clérigos y de sus feligreses, de las rentas, los gastos y los comportamientos humanos. Era un método de información inestimable a partir del que podía proceder a corregir conductas, crearse juicios de valor y llevar a cabo un mejor dominio material y espiritual de su territorio abacial.

Q ue dentro de la diócesis de Calahorra y la Calzada existiese un territorio ajeno a la jurisdicción del obispo como el que poseía el abad de San Millán era germen de numerosos conflictos. En España se cuentan hasta medio centenar las jurisdicciones nullios dentro de las diocesales a cargo de un obispo y todas ellas generaban constantes pleitos en cuanto a la elección de curas parroquiales, justicia eclesiástica y límites territoriales, además de los tocantes a la titularidad de las rentas y diezmos. Es evidente que tras el Concilio de Trento los obispos diocesanos salieron reforzados en sus funciones y competencias y constantemente emprendieron acciones para limitar los poderes abaciales dentro de sus dominios. Estas acciones aún contarían con más respaldo al calor del patronato regio y después con el regalismo del siglo XVIII.

En el contencioso mantenido entre los clérigos de Badarán y el Monasterio de San Millán de la Cogolla a raíz del plan beneficial de los años 1805 y siguientes y sobre el número de beneficiados que debían servir en la villa y el volumen de sus emolumentos, subyacía algo más que un problema de congrua, se estaba batallando por las competencias jurisdiccionales eclesiástica entre el abad y el obispo y sobre los derechos respecto a los diezmos. No por menos como temían los monjes, el obispo estaba "conducido de un verdadero interés por su monasterio y temiendo con fundamento que el obispo minoraría los diezmos de aquél". Y aún temía más el abad las disposiciones del Real Decreto de 9 de marzo de 1805 que facultaba al obispo de 
Calahorra para establecer los reglamentos de las iglesias parroquiales exentas eregidos dentro de la diócesis, en este caso, las del Monasterio de San Millán de la Cogolla ${ }^{16}$.

La visita del abad del monasterio de San Millán fray Hernando de Amescua a la parroquia de Badarán del día 5 de abril de 1636 y la de fray Miguel de Andueza de 3 de febrero de 1639 fueron similares a la expuesta más arriba de $1805^{17}$. Las tres visitas, más retazos de otras, nos van a servir para comprobar cuál era el alcance de las mismas, comprobando además cómo en todas ellas siempre se vela por la defensa de los intereses de los abades y se procura influir en la conducta de los feligreses.

El abad se presentó en la iglesia de la villa exhibiendo sus títulos y derechos, estando acompañado de su séquito y por el monje predicador Vicuña en 1636 y de los frailes predicadores Ambrosio Gómez y Benito Fernández en 1639. Fue recibido por el cura de la parroquia, en el primer año por Pedro Gómez, en el segundo por Francisco Fernández de O campo, y por los vecinos del pueblo al frente de los cuales estaba Pedro Matute, alcalde ordinario. El abad y su corte se aposentaron en las casas propiedad del monasterio. Al día siguiente, domingo, se celebró misa en presencia del abad y al terminar se procedió a la inspección de las capillas, alterares, pila bautismal, ornamentos, etc., indicando su estado de limpieza y orden. Después se celebraron varios responsos por los difuntos de la villa. Acompañado de numerosos feligreses la visita continuó fuera de la iglesia. A seguido se constituye una comisión al frente de la que va un subordinado del abad para visitar el hospital y recorrer las ermitas comprobando su estado material e indicando los arreglos que eran pertinentes. Al llegar a cada ermita se rezan varios responsos por los difuntos y se pide protección a los santos bajo cuya advocación se erigieron.

Como resulta de la visita, detalladamente anotada en diversos libros parroquiales y en especial en el Libro de Fábrica de la iglesia de Badarán, el abad exponía lo que era menester corregir. Lo primero, cumplir con lo que hasta entonces se había indicado en todas las visitas anteriores. Las misas de los domingos, como se ordenó a los beneficiados el año anterior, debían celebrase espaciadas en el tiempo y no todas juntas "para que los feligreses las oigan con más comodidad y los dichos clérigos sean mejor servidos" y si no lo cumplen habrá una pena de dos reales a pagar por cada cura. Que se amoneste y multe a quien "impida con sus inquietudes" la correcta celebración de los oficios; que los feligreses permanezcan quietos y observen con devoción los oficios.

La sacristía y los ornamentos deben "aderezarse", los corporales han de doblarse correctamente "haciéndolos llanos" y deben lavarse a mano, como los hábitos, por alguna religiosa de tres en tres meses. El mayordomo encarga-

16. AHN, Clero, libro 6063.

17. APB, Libros de Fábrica. 
do del alumbre de la lámpara del Santísimo Sacramento debe proceder con puntualidad de noche y de día pues se ha producido alguna omisión.

Q ue cumplan con las mandas que los difuntos dispusieron en sus testamentos, en especial, la de Andrés de Arenzana que designó fuesen entregadas todos los años a los pobres seis fanegas de trigo en tiempo de Pascua, "que no se pierda limosna tan lucida para los pobres"; también que se cumplan las de María de Angulo, las de Juan Fernández de O campo y otros. Las cofradías que llevan a cabo servicios litúrgicos paguen puntualmente por ellos. El asunto de las rentas y pagos de emolumentos siempre era un tema importante en las visitas.

Que no se deje de anotar en el libro de difuntos a los que mueran y que no se omita a los niños, que por ellos también suenen las campanas. En los entierros no se debe portar pendón, restringiéndose su uso para llevar el sacramento a los enfermos. Los cabos de año los han de celebrar los curas con puntualidad y los mayordomos que llevan las cuentas de los pagos por sepultura procedan con celeridad. La capa "principal" de terciopelo debe reservarse para casos especiales de aniversarios y no para "todos los aniversarios comunes".

En 1639 se dice que "por cuanto en la dicha iglesia y villa se tiene mucha devoción con el apóstol San Andrés y se tienen por su patrón muy antiguo y así es justo que su fiesta se celebre y rece con octava". Menos fervor se tenía en Badarán por San Millán, así que el abad insta a que se difunda su veneración por ser el "patrón de España" y en especial de la abadía, debiendo demostrar mayor devoción por él "Ios que en particular son hijos suyos como efecto son los que están debajo del auxilio, protección y amparo de la Real Casa de San Millán"

Es necesario que las primicias se paguen para el día de San Miguel so pena de excomunión mayor. En 1639 se dirá que el pan de la primicia se lo comen los ratones por estar en los aposentos de la iglesia por lo que debe depositarse, a sabiendas de que es propiedad de la iglesia de Badarán, en los graneros del monasterio. La limosna ordinaria ha de ser pedida los domingos y fiestas por el mayordomo, o una persona designada por él, y los feligreses deben abonarla porque de no hacerlo "defraudan a la Iglesia".

Q ue se lleven a cabo todos los reparos de las ermitas con pena de diez ducados de multa si no se hiciese, y también se proceda a un apeo de sus heredades y se ponga en un libro, después se den en arriendo sus heredades. Se haga lo mismo con el hospital advirtiendo que es necesario comprar algunas ropas y camas para el buen servicio. Se reparen, repongan y arreglen, las cruces que se hicieron para el calvario. También debe hacerse inventario de todos los bienes de la iglesia, que desde hace cuarenta años no se confecciona.

El cura enseñe o haga enseñar la doctrina cristiana a sus feligreses "como ya se le ha dicho otras veces" y que siempre esté al tanto de las cuentas de los mayordomos y del hospital y ermitas para evitar "inquietudes y pesadumbres" 
0 , dicho de otro modo, fiscalice su devenir y ponga en conocimiento del abad cualquier irregularidad. El abad también conmina a los clérigos a que tomen nota de los feligreses que comulgan en Pascua.

O bservamos cómo la preocupación de las visitas es tanto material como de conducta y religión, siempre tendente a preservar lo dispuesto hasta la fecha, amonestando cualquier quebranto en las obligaciones de los vecinos y curas hacia el monasterio e iglesia. Manifestando autoridad y obediencia hacia la jurisdicción del abad, procurando que ningún símbolo de tal potestad se destruya o se olvide. El propio ahínco por visitar las ermitas no esa más que una manifestación del dominio eclesiástico del abad en su territorio. Pensemos además que estamos ante una sociedad muy fácil de dirigir y que la religión es empleada como una herramienta más de sometimiento. La sociedad se caracteriza por una desmesurada religiosidad en la que todos los actos de la vida diaria están impregnados de piedad, en la que las competencias religiosas y civiles son muy difíciles de separar y donde las conciencias a través de la confesión, el sermón (en muchos casos el único medio de información para el común de los vecinos) o la enseñanza son fáciles de domeñar, de manera que quien decide sobre la religión y el nombramiento de los curas también decide sobre el modelo de actuación que se debe seguir.

El cambio de mentalidad y actitud que traerá el siglo XIX se dejó notar claramente en las mandas que se daban en las visitas abaciales. El abad pedirá que se promuevan por todos los medios la reforma de "las costumbres más deterioradas en el día; y constándonos cuán opuestas son a dicha reforma las asociaciones y reuniones nocturnas de personas de uno y otro sexo, y los bailes y juegos de ellas, las prohibimos enteramente". También atacará contra "Ios escándalos, excesos y pecados públicos, tales como robos, la embriaguez, las quimeras entre vecinos, las discordias entre las personas casadas, las palabras obscenas y tratos deshonestos, la indecencia y la superfluidad de los trajes, la irreverencia en los templos, la falta de respeto a los ministros de la religión y a las autoridades públicas y otros semejantes excesos"18.

Hemos dicho más arriba que como el abad de San Millán es nullios también tenía el derecho de nombrar a los curas o beneficiados que servían en la parroquia de Badarán. Igual que el obispo decidía qué cura debía servir en sus parroquias, salvando las particularidades locales, el abad hacía lo propio en las suyas. En el territorio de la diócesis de Calahorra y la Calzada fue costumbre inmemorial en muchas villas el derecho de nombrar a sus curas de almas de entre sus hijos bautizados en la pila de su parroquia por votación o aclamación popular. El derecho de que los vecinos eligiesen a sus curas paulatinamente fue sustituido por diversas fórmulas electivas indirectas (como nombrar a unos representantes que luego se encargarían de elegir al cura) o sencillamente se suprimió, quedando en manos del prelado diocesano la elección.

18. Archivo de San Millán de la Cogolla, Libro de visitas (1790-1833) citado por Sáenz RuizOlalde, J.L., 1992, pp. 382-383. 
El derecho de elección directa del cura por los parroquianos es relativamente frecuente encontrarlo en estas tierras hasta el siglo XVI, siendo los menos tras el Concilio de Trento. Badarán nunca tuvo el derecho de elegir a los clérigos que debían servir en su iglesia, era el abad de San Millán quien los imponía. Debido a los abusos que se cometían, el concilio tridentino recalcó que era necesario que los clérigos de las iglesias tuviesen una congrua (renta) suficiente para su sustento y que siempre que se pudiese se eligiesen a los servidores bautizados en las parroquias donde se iba a servir para mejorar la cura de almas y evitar que las rentas del beneficiado acabasen mudando de la villa empleándose en otras localidades. Tanto el rey con la elección de los obispos, los obispos con el nombramiento de los curas y los abades con sus frailes o curas de almas, incumplieron la norma cuando creyeron oportuno. Ahora bien, por el número de casos y porque es mucho más difícil encontrar a un fraile de tu congregación para situarlo como cura de alma o un clérigo secular acólito de tu orden regular, es raro la vez que cumplieron los abades con el derecho de los feligreses. El abad de San Millán nombró curas en Badarán a quién deseó incumpliendo las veces que le pareció un derecho inherente a los feligreses, tener un cura bautizado en su pila bautismal y residente en la villa.

El cura nombrado por el monasterio era el encargado del cuidado y gobierno de la iglesia, del alimento espiritual de los feligreses y el que administraba la parroquia en nombre del abad. Al principio todas las iglesias monasteriales, como la de Badarán, fueron atendidas por monjes-curas pero tras la reforma benedictina emprendida por Cisneros a comienzos del siglo XVI paulatinamente fueron sustituidos por clérigos seculares. En ocasiones el abad podía remover al cura de su puesto y en otras el cura podía abandonar la parroquia para atender otra. La provisión de curatos parroquiales se hacía mediante la imposición de un birrete sobre la cabeza del beneficiado mientras permanencia arrodillado ante el abad y tras haber comprobado que el candidato era merecedor del puesto por su conducta y preparación ${ }^{19}$.

Las críticas sobre la cultura de los clérigos, su preparación intelectual, sus conocimientos de las escrituras y del latín, de su conducta pública y privada han sido muy numerosas a lo largo de la historia. Es algo bien conocido que la preparación de los clérigos rurales era muy deficiente, que muchos carecían de moral adecuada, que su vida era en ocasiones licenciosa y que carecían de escrúpulos, siendo en muchos casos nulo su conocimiento doctrinal. También es cierto que este clima es más propio del siglo XVI que del XVIII, que los obispos y abades procuraron renovar su clero y dotarle adecuadamente, de igual manera que la Santa Inquisición tenía de entre sus más destacados fines erradicar cualquier conducta reprochable en el estamento eclesiástico, dentro de la abadía emilianense el Promotor Fiscal se ocupaba de estos asuntos. En el otro extremo, también son muchos los clérigos rurales que fueron ejemplo de

19. Sáenz Ruiz-O lalde, J.L., 1992, p. 362. 
sus parroquianos por su conducta y dedicación y que supieron escapar a las rencillas de las oligarquías locales y alcanzaron a defender a sus feligreses incluso de los atropellos de sus obispos y abades.

En el siglo XVI se siguieron varios largos procesos contra los curas de Badarán y Cárdenas por amancebamiento. En Badarán se computaron hasta cuatro casos. El más sonado de todos fue el de el cura Pedro Carrillo y María Salcedo datado en 1601. Un extracto del relato del proceso que se siguió contra el clérigo lo explica todo:

"es así que estando los susodichos y particularmente el dicho Pedro Carrillo, clérigo, obligados a vivir honesta y castamente y dar buen ejemplo de si no lo han hecho, antes de seis anos a esta parte han estado y están amancebados del cual amancebamiento la dicha María de Salcedo a parido seis u siete veces y la postrera fue a un año, poco mas u menos, en la dicha villa de Badarán que parió una niña que tiene y cría de pecho de lo cual a habido e hay en la republica de ella grande escándalo y murmuración"20.

A lo largo del siglo XVII constantemente se criticó el partidismo de algunos clérigos parroquiales por defender solo los intereses de la oligarquía local, en unos casos, y del abad en otros. Por el contrario, cuando fue elegido a comienzos del siglo XIX como cura de Badarán Benito Morga de 38 años de edad y natural de la villa, lo hizo después de presentar un currículo intelectual inmejorable y tras haber sobresalido en el examen al que se le sometió sobre conocimiento de las Sagradas Escrituras, Teología y otras materias competente a su cargo.

Hablemos por último de cómo la titularidad de las iglesias y la jurisdicción eclesiástica es el fundamento en el que se sustentan muchas de las posesiones materiales de los monasterios en las villas. El abad de San Millán, al poseer la iglesia de Badarán, también dispone de todas sus rentas, en especial del diezmo. Todos los feligreses tenían la obligación de satisfacer el diezmo ${ }^{21}$, la décima parte de lo que producían sus tierras y su ganado. Los propietarios de estos diezmos variaban según la localidad y podían ser el obispo, los cabildos de las iglesias, las fábricas de las parroquias, los señores, los particulares, etc. y los monasterios o sus abades. En Badarán nos encontramos con este último caso. El abad dispone de los diezmos y entrega a los servidores de la parroquia de la villa unas cantidades fijas para su sustento.

La jurisdicción eclesiástica sobre la parroquia de Badarán también le da derecho sobre otras rentas menores que, en muchos casos, cede a los curas como pago por sus servicios. Es el caso de las limosnas, que vimos más arriba, o de la cuarta funeral (pagos por sepultura), costes de misas, aniversarios, las oblaciones (ofrendas) y otras menudencias que se engloban en lo que se

\footnotetext{
20. AHN, Clero, leg. 3066.

21. Para saber más Ibáñez Rodríguez, S. (1999): El pan de Dios y el pan de los hombres: Diezmos, primicias y rentas en la diócesis de Calahorra (sS. XVI-XVIII). Logroño.
} 
conoce como los derechos de estola y pie de altar. Volveremos sobre estas rentas al hablar del poder económico del monasterio en Badarán.

\section{Control económico.}

El dominio del Monasterio de San Millán de la Cogolla sobre Badarán se redondeaba con el control económico del municipio. Junto a los derechos jurisdiccionales y los espirituales el monasterio ejercía sobre la villa un dominio económico. El cenobio de San Millán era el primer propietario de la tierra de cultivo de Badarán, otorgaba el mayor número de préstamos de dinero a sus habitantes, obtenía la mayor utilidad de los inmuebles que poseía en su jurisdicción y controlaba el mercado de granos y vino del municipio gracias a los diezmos y rentas. De los algo más de seis millones de maravedís que sumaba toda la riqueza de la villa de Badarán a mediados del siglo XVIII, el monasterio de San Millán de la Cogolla obtenía algo más de un millón de maravedís. Por tanto, la sexta parte de la riqueza de la villa de Badarán eran del cenobio emilianense.

Y el monasterio deseaba conservar esa posición. De las diez administraciones que el Monasterio de San Millán de la Cogolla mantuvo a lo largo de la Edad Moderna, la de Badarán ocupaba la cuarta posición en cuanto a ingresos, y la primera por el número de rentas obtenidas en una única villa.

Estructura de los ingresos obtenidos por el Monasterio de San Millán de la Cogolla en Badarán a mediados del siglo XVIII

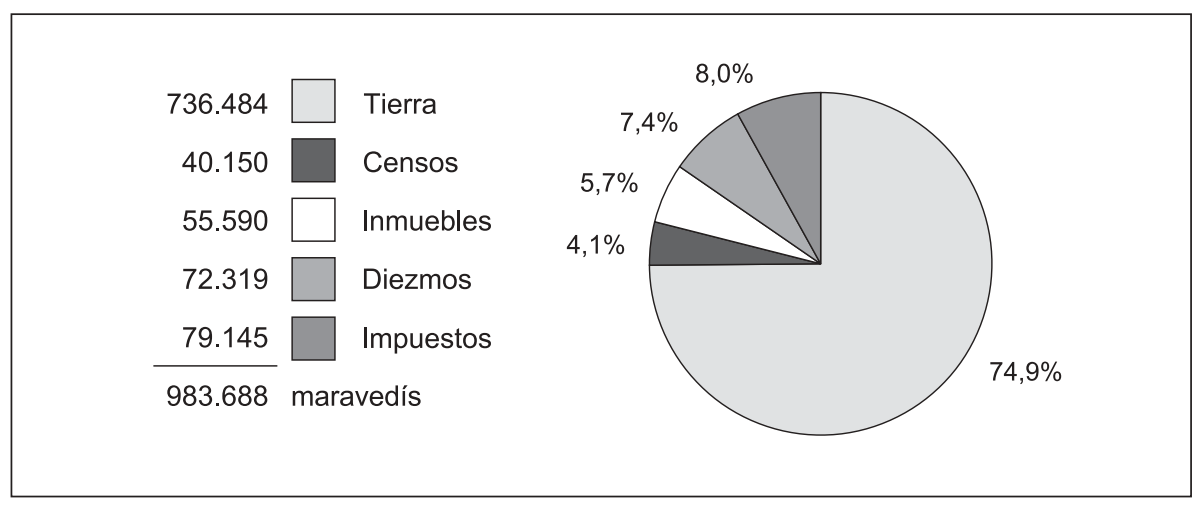

Aunque no existen datos irrefutables, todo parece indicar que el M onasterio de San Millán obtenía de la villa de Badarán un porcentaje mayor de riqueza en el siglo XVI que en el XVIII, pero por ejemplo la propiedad de la tierra fue mayor al tiempo de la desamortización del siglo XIX que en el quinientos. De los ingresos que obtenía el monasterio de la villa de Badarán en 1500 paulatinamente fueron disminuyendo las rentas procedentes de los derechos jurisdiccionales y de los censos, se mantuvieron las de los inmue- 
bles y crecieron las entradas procedentes de la propiedad de la tierra. El dinero que ingresaba el monasterio en concepto de impuestos se habían convertido en rentas fijas y su valor se fue depreciando con el tiempo, de igual modo, el monasterio arrastraba un elevado número de préstamos perpetuos en especie que también se vieron menguados. El valor de lo obtenido con los diezmos así como de los inmuebles fluctuó con el correr de los años. Donde mayor interés mostró el cenobio fue en su predio agrícola. La política general del Monasterio de San Millán de la Cogolla para toda su hacienda repartida por el norte de la Península Ibérica, y en especial en la de La Rioja, fue la de concentrar sus propiedades en un número limitado de municipios, básicamente en el valle del río Cárdenas y en Cihuri. Badarán era uno de los lugares preferentes donde el monasterio deseaba mantener una destacada propiedad de la tierra.

Pasemos ahora a analizar particularmente los ingresos que tenía el Monasterio de San Millán en Badarán y cómo ejercía el poder económico sobre la villa. Los ingresos que recibía el monasterio gracias a los impuestos ya los hemos visto en el apartado de la jurisdicción; en dinero sumaban a mediados del siglo XVIII un total de 79.145 maravedís y procedían de la pecha, la castillería, la martiniega, la polla de la botera o fumera y el yantar.

En cuanto a los préstamos en dinero o en especie, el Monasterio de San Millán de la Cogolla era el mayor prestamista en la jurisdicción de Badarán. De los 57 censos impuestos sobre vecinos y bienes de la villa a mediados del siglo XVIII, 26 eran del cenobio emilianense. El monasterio había prestado a los vecinos un montante de 19.914 reales de los que sus réditos le rentaban 1.181 reales al año. Estos préstamos se habían hecho, como se dirá a comienzos del siglo XIX, "bajo el compromiso de hipotecar, mediante escritura, los bienes y raíces de los vecinos en común y en particular"22 y constituían casi la tercera parte de todo el dinero dado en préstamo en la villa.

De los 26 censos dados por el Monasterio de San Millán en Badarán, 16 eran redimibles y los otros 10 censos eran perpetuos. De estos últimos, ocho se pagaban en especie, en trigo y cebada, y tenían como hipoteca fincas de tierra cultivada. Esta circunstancia denota además de que eran antiguos que casi todos eran arrendamientos de tierras monasteriales dadas a censo. En efecto, a mediados del siglo XVIII hasta catorce personas tenían como carga sobre sus tierras el pago de cantidades de trigo y cebada, e incluso alguna gallina.

Los censos perpetuos referidos también eran herencia de la permuta de bienes entre el Monasterio de San Millán y el de Nuestra Señora de la Estrella en 1577 y 1584. En el primer año el monasterio de la Estrella trocó con San Millán 20 fanegas, 3 celemines y 4 obradas de viña por las que se pagaba 8 
fanegas de trigo y dos capones ${ }^{23}$. En el año de 1584 San Millán entregó al de la Estrella toda la hacienda que poseía en Villarica y villas adyacentes, adquirida en 1327 a un vecino de Logroño: 13 heredades de 63 fanegas y 5 celemines de tierra en Villarica, 8 fincas con 24 fanegas y 4 celemines en San Asensio y 2 heredades con 5 fanegas en Hormilleja. Los jerónimos entregaban a cambio 14 censos perpetuos en Badarán fundados sobre 223 fanegas de sembradura y 87,5 obradas de viña, cuyos réditos montaban 50 fanegas de trigo y 25 de cebada. Con ello el M onasterio de San M illán conseguía rentas más próximas a su cenobio y se deshacía de heredades para las que años atrás había tenido dificultades para encontrar colonos e incluso las había dejado llecas. ${ }^{24}$

Los préstamos del monasterio se hicieron, menos en un caso, a particulares a título individual y el que más pagaba era un censo perpetuo de 148,5 reales de réditos anuales que debían satisfacer a partes iguales Manuel Martínez, Josefa Matute, Sebastián de U ruñuela, Roque Torrecilla, José Ruiz y Juan Pérez y que estaba impuesto sobre varias heredades de tierra. El resto de censos eran de menor cuantía. De entre ellos destaca también el que tenía que pagar la Villa, Concejo y Vecinos de Badarán. El préstamo había sido de 1.100 reales y los vecinos debían satisfacer todos los años 33 reales.

Una fórmula tradicional con la que aumentaban los predios las instituciones eclesiásticas en esta época era a través de los prestamos de dinero. Era muy frecuente que en determinados años el censatario no pudiese pagar los réditos a los que se había comprometido, lo más común porque el año había sido nefasto para las cosechas, y se veía obligado a un impago. Si la situación lo requería o era ya costumbre la demora, el monasterio podía proceder a denunciar la situación y obligar a que se sacase a subasta los bienes sobre los que se impuso el censo. Así el monasterio podía comprar en subasta y a bajo precio el bien hipotecado.

Los bienes de los vecinos de Badarán, como en el resto de España, también estaban en muchos casos gravados con cargas de carácter religioso: misas, aniversarios, limosnas perpetuas etc. que algún antepasado había impuesto sobre sus bienes al morir para allanar el camino de su alma al cielo. Pues bien estas cargas eran en muchos casos verdaderas losas para los vivos y tenían consecuencias tan graves como en el caso de los préstamos. Con el tiempo era imposible satisfacerlos y los nuevos propietarios debían deshacerse de los bienes sobre los que se impuso. Puesto que en Badarán es el monasterio de San M illán el que posee la iglesia y organiza su administración es fácil comprender que este fue otro de los medios que utilizó el cenobio para adquirir hacienda en la villa y proclamarse como el mayor de los poderosos.

O tra de las importantes fuentes de ingresos que poseía el M onasterio de San Millán de la Cogolla en Badarán era el derivado de la posesión de

23. AH N, Clero, leg. 3064.

24. AHN, Códices, 1034b, ff 29 y 352. Clero, leg. 3067. 
bienes inmuebles. Realmente no poseía más que seis inmuebles y un sitio, pero, y esto es lo importante, eran de calidad y a través de ellos ejercía simbólica y de forma tangible su dominio. Todos sumaban una utilidad de 55.590 maravedís. Las seis construcciones colocaban al monasterio por detrás de José Díez y Soto, quien poseía siete, pero el valor tasado por los inmuebles del cenobio le situaban en el primer lugar de la villa de Badarán acaparando, además, la cuarta parte (el 26,5\%) del valor de todos los inmuebles del municipio.

Los bienes inmuebles que poseía el monasterio en Badarán eran el edificio de la iglesia y sus dependencias, un hórreo cillero, dos molinos harineros, una casa, una bodega y un sitio inmediato a ella.

El edificio de la iglesia y su campanil simbolizan el dominio espiritual, toda la vida del municipio se rige por el toque de campanas: la hora del día, el tiempo de la fiesta y la oración, el nacimiento, la muerte, los sucesos trágicos, etc., de ello ya hemos hablado anteriormente, aquí sólo nos interesa resaltar el valor venal que, evidentemente, es inmensurable porque además de lo físico y espiritual su fábrica guarda la memoria de los vecinos (sus tumbas, los santos a los que adoran, es lugar de reunión, etc.) y sus tesoros artísticos (imágenes de vírgenes y santos, el retablo, las copas, patenas, sayales, etc.).

El monasterio poseía en Badarán una casa. El edificio era la residencia del fraile administrador de los bienes del cenobio y lugar de hospedaje del abad cuando visitaba la villa. A mediados del siglo XVIII se describió así: "tiene de ancho doce varas, e alto diez y de fondo treinta y cinco, con un huerto infructífero de ocho celemines de tierra cerrada de tapia confronta por un lado la calle que se va a la iglesia vieja y por otra con casa de Manuel Martínez vecino de esta villa, si la arrendara le darían seis ducados". Este inmueble además disponía de dependencias para el almacenamiento de granos y para dar cobijo a varios animales.

La uva que el Monasterio de San M illán recogía en Badarán se depositaba en la bodega de su propiedad. A mediados del siglo XVIII era "una bodega de vara y media de alto, cinco de ancho y diez de fondo y en ella se hallan dos tinos de cabida cada uno de cuarenta cargas y doscientas y noventa cántaras de beleces, confronta por un lado la senda que baja a las bodegas por otro la calle que va a dichas bodegas, si lo arrendara darían de renta anualmente tres ducados".

El monasterio también poseía "un sitio inmediato a la bodega de seis varas de ancho y diez de largo, confronta por cierzo la senda de las bodegas, por solano bodega de la O bra Pía de Tricio, no rédita cosa alguna".

La bodega monasterial disponía a comienzos del siglo XIX de un tino en el que entraban unas 60 cargas de uva y tres cubas, una de 104 a 108 cántaras, otra de 80 a 85 y la tercera de 70 cántaras más o menos. Como el número de bodegas, lagos y cubas que había en Badarán era reducido y muchos vecinos tan sólo disponían de un pequeño majuelo como viña, uti- 
lizaban las dependencias monasteriales para hacer vino. Todos los años algunos parroquianos le pedían al administrador de los bienes del cenobio que admitiese la uva de la cosecha propia en el tino del monasterio. Con ello el propietario de la uva se aseguraba el vino y el monasterio conseguía llenar el tino de forma más completa y así favorecer la fermentación, de igual modo llenaba más adecuadamente sus cubas y ahorraba gastos en jornales. Los aparceros contribuían personalmente en el pisado, saca de la uva, en llevar el orujo al trujal, en trujalarlo y en los primeros trasiegos. Claro que los problemas llegaban en el reparto, cuando había que distribuir ínfimas cantidades de vino entre los propietarios de la uva.

Una de las más importantes inmuebles que tenía el Monasterio de San Millán de la Cogolla en Badarán era el hórreo decimal donde recogía los granos de los vecinos. Como construcción este edificio era más un almacén que otra cosa y los materiales con los que estaba hecho eran pobres. Aún así era la única construcción que se levantaba en medio de las eras del municipio y era uno más de los símbolos del dominio del monasterio, en este caso de la exacción decimal, la plasmación material de la obligación de los vecinos de Badarán de pagar al cenobio emilianense con la décima parte de sus cosechas. H acia 1750 se describía así esta construcción: “U na casa hórreo que llaman La Cabaña Tejavana, de dos varas y media de alto, cinco de ancho y seis de fondo, sita en las eras de esta villa, confronta por cierzo era de Martín de Ramos, por solano otra de dicho monasterio, por ábrego senda que baja al Prado, y por regañón era del Concejo. Sirve para recoger los diezmos de dicho monasterio y si la arrendarían darían dieciséis reales anuales".

Los dos únicos molinos harineros a orillas del río Cárdenas existentes en la villa de Badarán, "con dos ruedas cada uno", pertenecían al monasterio de San Millán. Realmente todos los molinos y batanes junto al Cárdenas eran del monasterio. Teniendo en cuenta que estamos en una época en la que el principal sustento de los vecinos es la agricultura y que su alimentación depende casi en exclusiva del trigo, el poseer un molino harinero es una gran potestad. Todos los habitantes de Badarán debían utilizar los molinos del cenobio para convertir su grano en harina, también los de Cordovín y Villar de Torre. El dominio del monasterio no se reducía al ya importante poder sobre la vida diaria y alimenticia del municipio sino que además siempre esgrimió el derecho a ser el único que podía disponer de molinos en el municipio:

"En el capítulo quince de la Concordia entre el Monasterio de San Millán y el Consejo de Badarán dice: en cuanto a molinos en las riberas del río y término de este lugar sólo el monasterio los puede hacer, y no el concejo ni otro particular; y el monasterio pueda dar licencia a quien quisiere para hacerles"25.

El monasterio poseía los molinos y además hizo lo indecible por impedir que nadie más pudiese construir otro en la jurisdicción de Badarán ni en la

25. AHMB, Copia del Catastro de Ensenada, Libro 1o del estado eclesiástico... anotación en la página inicial sin numerar. 
de todo el valle del Cárdenas. Desde la constitución de la nueva villa de Badarán en el siglo XIV los pleitos sobre molinos entre los vecinos y el Monasterio de San Millán fueron constantes, no hay lustro que no se litigue algún asunto sobre ellos. El monasterio siempre mantuvo que la donación de Badarán por García Sánchez incluyó "todas las casas anejas, tierras, viñas, huertos, entradas y salidas, uso y costumbre,... montes, aguas... " y, por tanto, el construir molinos.

En 1525 los reyes Doña Juana y Carlos I enviaron una carta al corregidor de Santo Domingo para que velase por los asuntos tocantes a "la abadesa, priora, monjas y convento de Santa María de Cañas" que se veían lesionados por el Monasterio de San Millán en el uso de molinos en el valle del Cárdenas. Las monjas "se querellaban del abad, monjes e convento del monasterio de San Millán de la Cogolla... e otros vecinos de los lugares de Valle de San Millán e del lugar de Badarán que son del dicho monasterio, e de otras personas que protestaban declarar en la prosecución de la causa, que así era que teniendo el dicho monasterio de Cañas los molinos que dicen del Rojo en el río Valle de San Millán y teniendo derecho de echar el agua por do mejor pudiesen aprovechar los dichos molinos, los susodichos, dándose favor e ayuda los unos a los otros e los otros a los otros, en ciertos días de los meses de mayo e junio de este presente año habían ido a los dichos molinos e de hecho e por fuerza e con armas e habían amenazado a los molineros, e diciéndoles palabras feas e injuriosas e que los habían de poner por piedras por que no pasasen la dicha agua e que descalabraron ciertos molineros" 26 .

Durante la primera mitad del siglo XVI los vecinos solicitaron licencia al Monasterio de San Millán de la Cogolla para levantar y construir molinos y batanes, pero siempre se les denegó. Lo intentaron acudiendo a la justicia del Rey indicando que los monjes no les dejaban construir molinos ni ruedas de paños y tintes ni siquiera sobre sus propias tierras, pero lo hicieron en vano, la Chancillería de Valladolid sentenció en 1547 a favor del monasterio ${ }^{27}$. Después de otros intentos, en 1549 y $1556^{28}$, el monasterio impuso una Concordia a los vecinos de Badarán en 1559 en la que se acordaba que nadie podía construir molino alguno junto al río Cárdenas. Para poco sirvió, en 1587 de nuevo la Chancillería de Valladolid fallaría a favor del Monasterio e impidió los nuevos intentos de los vecinos por construir un molino. ${ }^{29}$

Pero era tanta la necesidad y tanto el daño que ocasionaba el cenobio obligando a todos los vecinos a moler en sus ruedas que, tras conseguir la Villa la condición de realengo, apurados por las malas cosechas de granos que se sucedieron esos años y con el ferviente apoyo de la oligarquía local, en 1629

26. Real Academia de la Historia, n으 26, p. 273, 6 de septiembre de 1525.

27. AHN, Clero, leg. 3098, Ejecutoria de 1547.

28. AHN, Clero, libro 6014, Ejecutoria grande de 1549.

29. Sáenz Ruiz-Olalde, J.L., 1992, p. 439. 
se pusieron manos a la obra y en la mañana del 4 de diciembre "el alcalde, regidores, alguaciles y otros vecinos con azadones, picos y otros instrumentos, empezaron a romper zanjas y acequias para edificar el molino"30. Por fin los vecinos habían logrado la autorización real para construir su anhelado molino libre del vasallaje de San Millán. En efecto, tras ofrecer al rey un donativo de cien ducados para mejorar las maltrechas arcas reales, la Corona les había dado autorización para construir el molino. Como se dijo entonces "el derecho de edificar molinos depende de facultad natural, y cualesquiera puede hacerlos en los ríos públicos que no sean navegables sin licencia del príncipe, ni de otro superior, por ser esta libertad de derecho de las gentes"31.

El suceso era algo que de ninguna manera podía tolerar el monasterio, se le faltaba a sus derechos, se creaba un deplorable precedente y podía ser germen que imitasen otras villas, como la de Cárdenas, que padecía las mismas circunstancias y que ya estaba ofreciendo otros cien ducados para conseguir licencia para un nuevo molino para provecho de todos. Además ya parecía evidente que los acontecimientos que se sucedían en Badarán escapaban por completo de la autoridad del abad. Las relaciones con la familia Torrecilla y quienes les secundaban eran de completa hostilidad, haciendo imposible la vida diaria y enfrentándose constantemente ante en los tribunales. El malestar era permanente y ya se habían producido enfrentamientos que no presagiaban nada bueno. En el consejo monasterial del 3 de noviembre se relató uno de ellos, el intento de un grupo de vecinos de Badarán de asaltar las dependencias del cenobio: "había sucedido cierto alboroto por el cual se daba indicio que querían cuatro hombres escalar la cabaña y además de eso hubo algunas palabras y amenazas contra el religioso que allí asiste y otros que procuran la hacienda de este monasterio". En esa ocasión los alborotos no llegaron a mayores y todo quedó en emprender acciones legales ante el Alcalde Mayor ${ }^{32}$. Bien distinto era lo que sucedió tras la mañana del 4 de diciembre.

El consejo monasterial de San Millán se reunió el mismo día que se abrieron las zanjas para el nuevo molino y acordaron dos actuaciones. Por un lado, apoyar al padre administrador de Badarán con la presencia de otros monjes y religiosos del cenobio para impedir la edificación por cualquier medio "porque era una vejación tan notable que a esta casa se le hace contra las ejecutorias y en detrimento de su hacienda". Y, por otro, emprender acciones legales y otras cualesquiera en las más altas instancias de la justicia y administración del país, procediendo a denunciar los hechos a la Chancillería de Valladolid y participando el monasterio en los donativos que solicitaba por estas fechas la Corona y sus servidores: "Y que se prometa de parte de esta Casa el dicho donativo, que es poco, para que no se edifiquen dichos molinos y

30. Archivo de la Chancillería de Valladolid, Ejecutorias, leg. 2580, “Contra los vecinos de Badarán que intentan construir un molino, 1633".

31. AH N, Clero, carpeta 1055.

32. AHN, Clero, leg. 6086, f. 61v. 
otros arbitrios que se han dado nocivos para ver si por esta vía se puede componer esta diferencia" 33 .

La determinación de los vecinos de Badarán era tan grande y su resentimiento hacia el cenobio tan sentido que los sucesos que siguieron fueron de pura violencia. Los monjes del monasterio se presentaron de inmediato en la villa apoyados con gente de su confianza y en clara actitud provocativa y los más, enardecidos. Aunque San Millán estaba solicitando la suspensión de la orden real, aún no disponían de sentencia a favor. Llegados los religiosos al lugar, como nos cuentan los testigos del cenobio, "todos los susodichos [vecinos] se habían conjurado y confederado, y dándose favor los unos a los otros, con voz del pueblo y tumulto, habían arremetido a los dichos religiosos y les habían dado muchos palos y coces y mojicones, y les habían arrastrado por el suelo y les habían hecho otros muchos malos tratamientos, poniendo manos violentas en los susodichos [monjes]". A Fray Juan de O rtega, padre mayordomo, a otros cuatro monjes y a varios acompañantes les pusieron en el cepo donde les increparon, apedrearon y golpearon con una pala; al padre Gabriel incluso le chamuscaron el rostro y a punto estuvo de ser quemado y abrasado "si no le hubiesen socorrido". Similar suerte corrió el padre fray Plácido de San Martín, del lugar de Cárdenas. Al llegar a Badarán le golpearon y le hicieron pedazos el manto "de manera que le habían dejado en cuerpo, sin zapatos, ni vestido, habiéndole arrastrado más de doscientos pies" para finalmente arrojarle indefenso al río.

Al día siguiente se presentó el provisor del Monasterio de San Millán con la intención de restablecer la concordia y restaurar los supuestos derechos usurpados a la abadía e indagar sobre los sucesos y los culpables. Pero fue imposible, nada más llegar a la villa "se le pusieron muchos de los vecinos, así hombres como mujeres, con diferentes géneros de armas y, en especial, espadas, alabardas [y] horcones" impidiéndole pasar adelante.

El monasterio salió mal parado de los sucesos, pero pronto lograría recuperar su altivez. Sus papeles fueron movidos con celeridad en la Corte logrando una pronta respuesta gracias a los donativos. En junio de 1630 se denegó el derecho concedido a Badarán y todo el asunto fue remitido a la Chancillería de Valladolid donde se tachó to do lo referente al "derecho natural" y "libertad de las gentes" para construir molinos que le había permitido a Badarán comenzar a construir el suyo y se alegó que no se podían dar tales licencias en este caso porque ocurría "que otro que tenga molino fabricado en el dicho río, haya adquirido legítimamente por prescripción de que otro no edifique, porque en este caso cesa la dicha facultad natural, concurriendo para dicha prescripción el requisito de la prohibición que la de principio" y que no había lugar a una nueva obra "cuando resulta perjuicio considerable, como si el que tiene edificado se le impidiese el uso del agua, de forma que no moliese el suyo con libertad". En fin, sin entrar en estas enrevesadas disquisiciones, lo que el monas-

33. AHN, Clero, leg. 6086, f. $63 \mathrm{v}$. 
terio había logrado era imponer el viejo principio de que cuando recibió Badarán en la Edad Media también se incluían las aguas y los ríos; de nada sirvió tampoco alegar que Badarán ya no estaban bajo la jurisdicción de San Millán, según los oidores de la Chancillería los derechos sobre la edificación de molinos procedía del dominio directo.

En el municipio de Badarán pronto llegó la normalidad y la resignación, habría que obedecer al monasterio. Gracias al apoyo de una parte de los habitantes de la villa y de los testimonios de los frailes y religiosos agredidos, el Monasterio de San Millán logró identificar y culpar a quienes habían encabezado todos los sucesos poniendo sus nombres en manos de la justicia. También procedería a la demolición de la obra llevada a cabo para levantar el molino y consiguió mantener quieto el derecho a construir molinos junto al Cárdenas. U nos años más tarde, en 1632, la Chancillería de Valladolid expidió una Carta Ejecutoria a favor del Abad y monjes de San Millán dando cuenta de los sucesos, de los culpables y de los castigos impuestos. Varios vecinos fueron condenados a penas de destierro, otros al pago de multas y, en conjunto, to dos tuvieron que abonar la nada despreciable cantidad de 104.646 maravedís para enmendar sus actuaciones y pagar a la justicia. Esa cantidad subió a los 136.000 maravedís (4.000 reales) después de que el monasterio incluyese otras partidas menores. El cenobio, por su parte, ya había emprendido diversas acciones represivas: sermones condenatorios desde el púlpito, acusaciones de excomunión, reforzamiento de sus derechos jurisdiccionales, apremio a los particulares que tenían contraídas deudas con el cenobio, vigilancia de la calidad del grano entregado en el diezmo e incluso la adquisición de tierra y heredades de las personas poco afectas a los monjes ${ }^{34}$.

Los vecinos de Badarán habían sido condenados y algunos habían pagado con creces su atrevimiento pero no por ello se sentían doblegados. Tras los terribles sucesos de 1629 aún continuaron peleando para construir un molino que convirtiese su grano en harina y así escapar del poder que ejercía el monasterio a través de este monopolio. Algunos ejemplos lo atestiguan, como las averiguaciones y certificaciones de jurisdicción y señorío de 1679 en el pleito que se seguía en Valladolid sobre "el edificio del molino y otras cosas", o como las distintas apostillas y comentarios que en documentos de otro tenor durante el siglo XVIII aluden o bien al derecho del cenobio a ser el único con potestad de disponer de molino o de los vecinos del pueblo a poder construirlo.

Como vemos el Monasterio de San Millán de la Cogolla es el que mayor utilidad obtiene de sus inmuebles en Badarán. Es el más rico en este sector. De entre las construcciones destacan los molinos harineros, que posee en monopolio y que le permite ejercer un mayor poder y las simbólicas construcciones de la iglesia y el hórreo decimal. Ya hemos dicho más arriba que el monasterio es el propietario de los diezmos de la villa, veámoslo.

34. AHN, Clero, libro 6086. 
La propiedad de los diezmos de los vecinos de Badarán, como ya dijimos, era principalmente del Monasterio de San Millán de la Cogolla. Solo una pequeña parte de las décimas escapaban del control del cenobio: la mitad de los de las heredades de los vecinos con tierras en el antiguo dezmatorio, campanil y coto redondo de la iglesia de San Juan de Villorquite. El padre fray Benito Fernández, monje de la abadía y administrador y apoderado del monasterio en Badarán en 1751 indicó que el cenobio "recibe y percibe todos los frutos de diezmos que los términos de este pueblo se diezman por los vecinos y forasteros a excepción de la mitad de los del territorio dezmatorio de San Juan de Villorquito" ${ }^{35}$. En la práctica, el monasterio se llevaba la casi totalidad del diezmo de toda la jurisdicción de Badarán, un $80 \%$, porcentaje que seguro era algo mayor por el diezmo que no entregaban las heredades del cenobio que había logrado eximir.

Los diezmos reportaban al Abad y Monasterio de San Millán unos elevados ingresos y sin apenas costes. Los vecinos entregaban la décima parte de todo lo que crecía en sus tierras y de todas las crías que parían sus animales. El valor de los diezmos fluctuaba en función de la cosecha de cada año y de los precios, aún así podemos conocer su valor aproximado en varias fechas. De media entre 1537 y 1541 le reportó 600 reales, entre 1588 y 1591 unos 4.500 reales, entre 1746 y 1750 la cantidad de $3.476,7$ reales brutos y como promedio de los frutos de 1771 a 1775 una cantidad superior a los 10.000 reales. Estos datos pueden que nos digan poco, pero se entenderá más su importancia si observamos que de todas las rentas que el Monasterio de San Millán obtenía de Badarán hacia 1750 el diezmo representaba el 11,5\% de sus ingresos y que casi seguro en el siglo XVI ese porcentaje estaba muy próximo al 15\%.

Además del valor inherente de los frutos que se obtienen con el diezmo, éste reporta otros beneficios. El primero y más importante, es que convertía al monasterio en el mayor almacenista de grano del municipio, sin los molestos gastos de producción, el cenobio era el que controlaba, y en ocasiones monopolizaba, la compraventa de los productos alimenticios esenciales del municipio. Poseía, sin más título que el derecho del diezmo, la décima parte del trigo, de la cebada, del vino, de la fruta, del lino y cáñamo, de las alubias, arvejas y garbanzos, de los corderos, cerdos y pollos que nacían, de la lana, en fin, de todo. Entenderemos entonces que en los años de malas cosechas y de carestía fuese acusado de acaparador y que los vecinos lo mirasen con recelo porque acostumbraba a decidir sobre los precios de los frutos. Era imposible que los habitantes de Badarán escapasen de este dominio del monasterio porque el cenobio no sólo manifestaba su poder en Badarán, también lo ejercía en los municipios colindantes (Cordovín, Cárdenas, Villaverde, etc.). A través de los diezmos el monasterio de San Millán decidía sobre el mercado de granos del Valle del Cárdenas e incluso tenía una posición dominante en toda el área de Nájera.

35. AH PLo, Catastro, caja 114, Certificaciones. 
El monasterio también utilizaba el diezmo para facilitar el arrendamiento de sus tierras, encontrar mejores postores y mitigar el efecto de la renta, asunto que veremos más adelante. O tro beneficio que otorgaba la propiedad del diezmo a quien quisiera hacer uso de él, era que permitía aumentar la hacienda. Está demostrado que la propiedad del diezmo en el Antiguo Régimen fue un inmejorable vehículo para acrecentar el predio de muchas instituciones eclesiásticas y el Monasterio de San Millán no fue una excepción. El dinero que obtenía de los frutos diezmados y la posición de poder que le otorgaba la titularidad del diezmo al Monasterio le permitían acceder con ventaja a las compraventas y subastas de tierras así como a presionar a los propietarios para que se plegasen a los intereses del cenobio.

El diezmo, como hemos dicho, lo entregaban los feligreses porque era el sustento de sus ministros, de los servidores de su iglesia y de quienes a través de la cura de almas les permitiría acceder a Dios. Así lo entendían y así se les repetía machaconamente desde los púlpitos. Era el sustento de sus párrocos para que no tuviesen que malgastar su tiempo en trabajos banales y se dedicasen a la oración, la confesión, al sacrificio de la misa, asistiesen a los enfermos, en definitiva, dedicasen su tiempo en exclusiva al alma de cada parroquiano y de toda la comunidad. Pero como vemos, el Monasterio de San Millán era el que recibía el diezmo, a cambio tenía la obligación de entregar una parte de los frutos decimales a los cuatros eclesiásticos que servían en el cabildo de la iglesia de Nuestra Señora de la Expectación de Badarán. Concretamente, y como se decía a mediados del siglo XVIII "tiene la obligación dicho monasterio de dar al cabildo de beneficiados de la parroquial de esta villa por congrua sustentación ciento y treinta fanegas de trigo anualmente y cien cántaras de vino". En 1574 también eran cuatro los servidores y el monasterio les entregaba veinticinco fanegas de trigo y cien cántaras de vino. Durante el siglo XVI el monasterio entregó sólo entre el 15 y el $20 \%$ de los diezmos para sustento de los clérigos de Badarán; en el siglo XVIII el porcentaje era mayor, entre el 30 y el $50 \%$ del valor de los frutos diezmados. Los clérigos de Badarán también habían logrado que las tierras de su beneficio no pagasen diezmos tanto si la las labraban directamente como si las daban a renta.

Como el monasterio disponía en Badarán de un monje administrador, ayudado cuando era preciso por varios operarios, la recolección y almacenamiento del diezmo era ágil y acarreaba pocos gastos. M enos aún desde que el cenobio acordó entregar a los vecinos las 25 cántaras de vino el día de San Juan a cambio de conducir los frutos decimales al hórreo y bodega monasteriales. El monasterio acostumbró a recibir en especie los frutos decimales mayores (trigo, cebada, centeno, avena y vino) y el resto, los menudos, darlos en arriendo debido al alto coste de recolección y almacenamiento, piénsese que cada fruto se entregaba en una fecha distinta del año. Esto no quiere decir que determinados años sea el propio monasterio quien reciba todos los frutos en especie, mayores y menudos. Cuando los menudos también se administraban, el monje daba cuenta de su número al monasterio, los vendía y después de deducidos los gastos enviaba el dinero a la casa matriz. 
Las ausencias del monje administrador hacía del cobro de rentas y diezmos de Badarán un asunto desmañado y ocasión para el fraude y engaño. En 1800 el monje residía en la granja de San Martín de Soto, próxima a Badarán, y su ausencia fue origen de "algún desfalco en los diezmos" ${ }^{36}$. La casa matriz de San Millán debía vigilar con cuidado el proceder de los monjes administradores de su hacienda en las diferentes granjas y villas, procurando tomar nota de sus cuentas y vigilando su comportamiento entre el vecindario. De igual forma el padre administrador estaba obligado a supervisar de cerca de sus colaboradores durante todo el proceso decimal. Como escribió el padre Marcillach, administrador en Badarán entre 1824 y 1832, los operarios debían no cometer fraude "en medir y contar", debían numerar "en voz alta" y "al mismo tiempo que ellos van midiendo y contando, el padre administrador va asentando en un pliego de papel que lleva ya dispuesto las medidas conforme las van cantando" ${ }^{37}$.

El administrador de San Millán debía procurar siempre disponer de un criado hábil, que supiese leer y escribir, para que anotase adecuadamente en las tazmías el nombre del diezmero y las cantidades entregadas. Los días de recolección decimal eran de un constante desasosiego, el monje debía ir y venir una y mil veces de las eras al hórreo y a la casa abacial, constantemente atento para que nadie cometiese fraude, sudoroso del trajín y la responsabilidad, vigilante porque todo se desarrollase adecuadamente y nadie osase sisar nada a Dios y al abad. Tras recoger el grano, que en el mes de la cosecha se empezaba con la cebada, se seguía con el trigo, la avena y la comuña o centeno, se debían contar con un buen puñado de jornaleros: cuatro empleados en medir y tener los costales dentro del hórreo decimal, dos con caballerías transportando el grano hasta el almacén abacial y uno más esperando en el granero para ayudar en la descarga, vigilar el grano y removerlo cuantas veces fuese necesario. En la década de 1820 se les pagaba a los hombres que asistían en la partición a 4 reales de jornal, a los que lo hacían con caballería 8 reales, y todos ellos mantenidos. Antes de empezar a trabajar, aguardiente; después almorzar; a las diez, bocadillos; al mediodía la comida; un descanso para un trago entre comida y merienda; la merienda y, casi siempre, también cena. Si se acababa pronto, lo que sucedía en los años que había poco grano, se les daba pan y vino por la tarde, y después merienda-cena a un tiempo y temprano para que marchasen cuanto antes, que todo eran gastos. El administrador dirá, a la vista de todo ello, que es mejor contratar a jornal y a seco, aunque se pague algo más, que son muchos los desalientos y los costes.

Por lo común, el dinero que obtenía el Monasterio de San Millán de los diezmos menudos de Badarán y de otras villas, se destinaban exclusivamente al mantenimiento de la sacristía del cenobio y al pago de las costas de los

36. AHN, Clero, libro 6082.

37. Archivo de San Millán de la Cogolla, Libro de gobierno de Badarán, f. 235v. Tomado por Sáenz Ruiz-O lalde, J.L., 1992, p. 406. 
pleitos locales. Los diezmos mayores acababan en las arcas del monasterio, no necesariamente depositados allí, pero sí formando parte de las cuentas generales del cenobio y, por tanto, para engrandecimiento y ornamento del mismo. Cuando se entregaban pequeñas porciones en especie de queso, gallinas, cerdos, frutas, etc., se destinaban al consumo del fraile y ayudantes residentes en Badarán. La uva se convertía en vino en la bodega que el cenobio poseía en la villa y de allí se sacaban para el consumo y venta.

Los corderos que el monasterio obtenía de Badarán y de toda la zona del Valle del Cárdenas se conducían hasta San Millán y se destinaban al consumo de la comunidad. En las primeras décadas del siglo XIX se acordó entregar a los curas de la parroquia de Badarán algunas partes de los diezmos menudos y de los corderos. De éstos les correspondía a los beneficiados la tercera parte. Para tomar del acervo común los que les tocaban se juntaban curas y administrador a finales de junio y seleccionaban del hato entre los mejores, los medianos y los peores la parte que les correspondía. En estas fechas también estaba por costumbre que se matara el mejor cordero diezmado y se comiese en la casa del administrador monasterial convidando a diversas personalidades. De igual forma el organista y los cantores de la iglesia acudían a pedir un cordero para merendar. Pero estas costumbres eran muy mal vistas por los monjes emilianenses así que en la celosa administración de Mauro Marcillach se les dio fin.

El Monasterio de San Millán de la Cogolla era el mayor propietario de tierra en Badarán. En efecto, el cenobio poseyó entre la tercera y la sexta parte de la tierra labrantía del municipio durante los siglos XV al XIX. Los distintos apeos llevados a cabo por el cenobio emilianense para reconocer sus heredades en Badarán, las cuentas de varios administradores de la hacienda, los informes de los vicarios del cenobio, la información facilitada por el Catastro del Marqués de la Ensenada, los autos para mensurar las propiedades del monasterio en el Trienio Liberal y las informaciones resultantes para la venta y enajenación de los bienes de los conventos de los regulares tras la desamortización de Mendizábal, nos han facilitado una valiosa información sobre la propiedad de la tierra del Monasterio de San Millán de la Cogolla en Badarán y el resto de su dominio. Como resultas de ellas podemos comprobar que la presencia del monasterio en Badarán es más que notable. Era el primer propietario, sus heredades eran las más grandes y las de mejor calidad, era capaz de obtener de su predio los mejores rendimientos y, en suma, ejercía un claro control en la localidad sobre un bien primordial, la tierra, tanto a través de su tenencia como de las fórmulas de administrarla, preferentemente a través del arrendamiento. 
Superficie de tierra cultivable del Monasterio de San Millán de la Cogolla en Badarán, en fanegas

\begin{tabular}{|c|c|c|c|c|c|c|c|c|}
\hline Año & $\begin{array}{c}\text { N } 0 \\
\text { here- } \\
\text { dades }\end{array}$ & Sembradura & Viña & Total & $\begin{array}{c}\% \text { sobre la } \\
\text { terra } \\
\text { cultivable }\end{array}$ & Índice & $\begin{array}{c}\text { Tierra sobre la } \\
\text { que tiene } \\
\text { control }\end{array}$ & $\begin{array}{c}\text { Tierra de } \\
\text { existencia } \\
\text { desconocida }\end{array}$ \\
\hline 1534 & & 684,6 & 67,6 & $\mathbf{7 5 4 , 2}$ & 24 & 100 & 935,7 & $?$ \\
\hline 1597 & & 710,2 & 75,2 & $\mathbf{7 8 5 , 4}$ & & 104 & 972,7 & $?$ \\
\hline 1750 & 509 & $1.079,6$ & 25 & $\mathbf{1 . 1 0 4 , 6}$ & 21,1 & 147 & $1.243,1$ & 25,5 \\
\hline 1781 & 473 & $1.114,4$ & 14,4 & $\mathbf{1 . 1 2 8 , 8}$ & 16 & 150 & $1.289,2$ & 38,8 \\
\hline 1821 & 492 & & & $\mathbf{1 . 2 4 0 , 9}$ & & 165 & $1.403,1$ & $?$ \\
\hline 1824 & & & & $\mathbf{1 . 2 0 1 , 9}$ & & 160 & $1.364,5$ & 19,1 \\
\hline 1836 & 582 & $1.250,2$ & 3,6 & $\mathbf{1 . 2 5 3 , 8}$ & & 167 & & \\
\hline
\end{tabular}

Fuente y comentarios:

El "Total" sólo incluye la superficie sobre la que el monasterio tenía una propiedad plena. En la columna "Tierra sobre las que tiene control" se incluyen las heredades dadas en censos perpetuos, pero no de otras instituciones como la iglesia parroquial o el hospital de Badarán que en ocasiones constan dentro del patrimonio emilianense. La "Tierra de existencia desconocida" es aqueIla de la que no se tiene constancia de propiedad por desconocer su localización o no disponer de título de propiedad; no está computada en ninguna columna. El "\% sobre la tierra cultivable" es cierto en 1750, en los otros dos casos son extrapolaciones muy fiables.

Los datos de 1534 y 1597 son de los apeos de AHN, Clero, libro 6034 y 6058, por gentileza de Francis Brumont. Ambos apeos incluyen sólo tierra que con seguridad era del monasterio.

Para 1750 se ha procedido al recuento de las propiedades del monasterio según las respuestas particulares del Catastro de Ensenada, AHPLo, cajas 114 a 118.

Las cifras de 1781 son según el apeo de Bayo de Archivo de San Millán, legajo 39/28. La extensión de 1821 es la que ofrecen los expedientes de enajenación del Trienio Liberal que no se Ilevaron a la práctica en AH N, Clero, legajo 3067. Las cifras de 1824 corresponden a los apeos del administrador Mauro Marcillach en Archivo de San Millán, Libro de gobierno de Badarán. Las cifras de los años 1781, 1821 y 1824 están elaboradas a partir de los datos de Sáenz Ruiz-O lalde, J.L., 1992, San Millán... pp. 71-72.

Por último, los datos de 1836 son de AHN, Clero, legajo 4542b, Clero regular. Estado de fincas rústicas y urbanas que pertenecieron a monasterios y conventos suprimidos. Logroño 1841.

El número y extensión de tierras del Monasterio de San Millán en Badarán era ya muy elevados en el siglo XVI. En este siglo el cenobio dispuso de control sobre la tercera parte del terrazgo cultivado, computando aquí la propiedad directa con la derivada de tierra dada en censo, y aún sería mayor si sumásemos las tierras de la parroquia y el hospital de la villa que administraba como señor que era de ellos. Si consideramos que la tierra es esencial en esta época tanto como bien que da riqueza como por el fruto que de ella se obtiene, esta cifra ya advierte con claridad hasta dónde alcanzaba el poder del monasterio en la villa. 
La tierra que podía cultivarse en Badarán fue en aumento con los siglos gracias a sucesivas roturaciones. Durante el siglo XVI provocados por el crecimiento de la población, durante el XVII para poder obtener algunos ingresos extras con los que hacer frente a los cuantiosos gastos que se derivaron de la compra del señorío de la villa, ventas a las que habría que añadir las usurpaciones de algunos vecinos. En el siglo XVIII, casi sólo durante su segunda mitad, de nuevo la presión demográfica unida a los intereses particulares forzaron a la puesta en cultivo de nuevas tierras a costa de los ejidos y el monte. Desde finales del XVIII se unen otros motivos, las desamortizaciones de los bienes comunales en tiempos del ministro Godoy y, después, la venta de propios en tiempos de los franceses más la ocupación de terrazgo en años de desgobierno. Igual que aumentaba la extensión de la tierra cultivada en Badarán, el Monasterio de San Millán aumentó con los siglos la extensión de su propiedad pero lo hizo a un ritmo menor. Si en el siglo XVI el monasterio controlaba de entre el 24 y el $30 \%$ de la tierra cultivable, en el XVIII era del 16 al $24 \%$.

Pero este menor crecimiento del predio monasterial no debe esconder la verdadera dimensión del volumen de tierra que poseía. Las mayores haciendas del Monasterio de San Millán durante toda su historia han estado en Cihuri, el Valle de San Millán y Badarán. En otros municipios, como Cárdenas o Cordovín, la porción de terrazgo que poseía era muy elevada pero en extensión no eran comparables a la de los tres lugares mencionados. Además, en villas como Badarán ya disponía de tal acumulación de tierras que para poder encontrar renteros debía de permitir que existiese un adecuado número de heredades libres que incentivasen e hiciesen atractivo a los moradores la permanencia en la villa 0 , si la época lo requería, atrajese nuevos vecinos. Si en el siglo XVI el monasterio poseía de forma plena entre 754 y 785 fanegas de tierra (158 y 165 has), a mediados del siglo XVIII era de 1.105 fanegas (232 has) lo que suponía un incremento del 40 o 47\% del terrazgo (se pueden ver con precisión los datos en los cuadros adjuntos). Pero estas cifras no fueron el límite de la propiedad del monasterio en Badarán. La mayor extensión la alcanzó en el momento de la exclaustración y cierre del M onasterio de San Millán de la Cogolla en 1836. En las cifras manejadas en 1841 para la venta de todo el terrazgo que poseía el cenobio en Badarán se anotan 1.254 fanegas (263 has).

Fanega a fanega, aunque fuese de forma pausada, el monasterio se fue haciendo con un creciente número de tierras en Badarán. El monasterio siempre mantuvo el puesto más destacado como propietario de tierra en la villa aunque aumentase considerablemente el número de hectáreas puestas en cultivo en el municipio. Llegó a ser tanto el volumen de heredades que el segundo propietario del municipio, el Monasterio de Valvanera, sólo tenía la cuarta parta que el cenobio emilianense.

La mayor parte del terrazgo que el Monasterio de San Millán poseía en Badarán era tierra sembradura. Ya desde el siglo XVI el cenobio manifestó desapego por la viña. Es evidente que el terrazgo dedicado a la vid creció en 
Badarán durante el siglo XVI, como nos lo demuestra el aumento del volumen de las cosechas de vino, pero el monasterio prefiere la tierra blanca, de ahí que desde 1534 a 1597 la viña en su predio pasase de las 338 obradas a las 376 cuando el terrazgo dedicado a la vid creció apreciablemente en el municipio. Durante el siglo XVII el cenobio mantuvo un número similar de obradas pero poco a poco se fue desprendiendo de ellas o las convirtió en tierra blanca. A mediados del siglo XVIII ya tan sólo eran 125 obradas y en las décadas siguientes la tierra del monasterio dedicada a la vid únicamente tenían un valor testimonial dentro de su dominio en Badarán. En 1836 se mencionan solamente 18 obradas.

La superficie de viña que el monasterio poseyó en Badarán fue siempre reducida pero era la suficiente como para que los monjes fuesen los mayores propietarios vitícolas del pueblo. A mediados del siglo XVIII disponía de 125 obradas en 26,5 heredades que le hacían el mayor propietario, seguido del natural José Díez y Soto con 9 heredades y 206,4 obradas. Las heredades de vid del monasterio parece que fueron grandes en el siglo XVI, cuando se menciona en 1597 una pieza de 80 obreros (16 fanegas) en el arrendamiento de "Sobrevilla"38. Pero no tan extensas en el siglo XVIII pues la viña mayor que se menciona es de 25 obradas (5 fanegas) y además no saben los monjes de su existencia. A mediados del setecientos las viñas del monasterio tenía de media 4,7 obradas de extensión por heredad, las del resto de propietarios 3,3 obradas.

El desapego por la viña no es exclusivo del Monasterio de San Millán, el conjunto de los grandes monasterios riojanos también lo manifiesta, quizá excluyendo el caso del Monasterio de la Estrella. La viña representaba un porcentaje bajo dentro de sus predios, rara vez por encima de la cuarta parte. Cierto es que lo del Monasterio de San Millán en Badarán es excesivo, pero tiene una explicación sencilla. Según disminuía la superficie de viña en Badarán el cenobio la aumentaba considerablemente en Cordovín. De las 68 has que aumentó toda la hacienda emilianense en La Rioja entre 1752 y 1841, 37 fueron de viña y si en la primera fecha disponía de vid en 18 lugares, en 1841 ya tan sólo había en 10. El monasterio era propietario en Cordovín en el año de 1752 de la cuarta parte de la tierra cultivada; de ésta, el 41\% (73 has) eran viña. En 1841 la vid en manos del monasterio alcanzaba en Cordovín las 123 has, el $57 \%$ de toda su propiedad en la villa ${ }^{39}$. Además de producir vino en otros lugares en los que disfrutaba de mejor infraestructura, el monasterio ingresaba el vino que le llegaba hasta sus bodegas gracias a la recaudación del diezmo de las múltiples villas donde lo disfrutaba.

38. AHN, Clero, Libro 6034.

39. Ibáñez Rodríguez, S., 1998, «El dominio rústico del monasterio de San Millán de la Cogolla en el siglo de su clausura (1752-1841)», Brocar 22, pp. 121-136. 
Número de heredades, superficie y valor de la tierra del Monasterio de San Millán en Badarán a mediados del siglo XVIII

\begin{tabular}{|c|c|c|c|c|c|c|c|c|c|c|}
\hline & & Número & de here & ades & Extensió & n en fan & gas & Valor & en duca & ados \\
\hline Tipo & & Badarán & Mona & sterio & Badarán & Mona & terio & Badarán & Monas & terio \\
\hline Tierra & clase & $\mathrm{n}^{0}$ & $n^{0}$ & $\%$ & fns & & $\%$ & dcs & $d c s$ & \\
\hline Sembradura & $1 \underline{a}$ & 93,7 & 14,5 & 15,6 & 105,0 & 54,4 & 51,9 & 813,5 & 421,5 & 51,9 \\
\hline de regadío & $2^{a}$ & 27,6 & 4,0 & 14,5 & 50,4 & 4,3 & 8,5 & 288,3 & 24,5 & 8,5 \\
\hline anual & $3^{\underline{a}}$ & 12,5 & 1,0 & 7,4 & 33,8 & 0,3 & 0,8 & 91,2 & 0,8 & 0,8 \\
\hline & & 133,8 & 19,5 & 14,6 & 189,2 & 59,0 & 31,0 & $1.193,0$ & 446,7 & 37,4 \\
\hline Sembradura & $1 \underline{a}$ & 10,3 & & & 6,4 & & & 33,1 & & \\
\hline de secano & $2^{a}$ & 31,0 & & & 13,9 & & & 39,1 & & \\
\hline cadañera & $3^{\underline{a}}$ & 11,0 & & & 5,2 & & & 7,1 & & \\
\hline & & 52,3 & $\emptyset$ & $\varnothing$ & 25,4 & $\varnothing$ & $\emptyset$ & 79,3 & $\varnothing$ & $\varnothing$ \\
\hline Sembradura & $1 \underline{a}$ & 173,1 & 18,2 & 10,6 & 274,2 & 89,4 & 32,8 & 797,7 & 260,1 & 32,8 \\
\hline de secano & $2 \underline{a}$ & $1.327,3$ & 150,4 & 11,3 & $1.695,4$ & 390,3 & 23,0 & $3.170,7$ & 729,7 & 23,0 \\
\hline de año y vez & $3 \underline{a}$ & $1.784,8$ & 213,9 & 12,0 & $1.960,0$ & 454,1 & 23,2 & $2.114,7$ & 489,8 & 23,2 \\
\hline & & $3.285,2$ & 382,5 & 11,6 & $3.929,7$ & 933,8 & 23,8 & $6.083,11$ & $.479,7$ & 24,3 \\
\hline Viña & $1 \underline{a}$ & 29,9 & 1,0 & 3,3 & 24,0 & 1,1 & 4,6 & 95,5 & 4,4 & 4,6 \\
\hline & $2^{a}$ & 105,8 & 7,0 & 6,6 & 83,1 & 9,1 & 11,0 & 188,9 & 20,7 & 11,0 \\
\hline & $3 \underline{a}$ & 303,7 & 18,5 & 6,1 & 193,3 & 14,8 & 7,7 & 219,8 & 16,8 & 7,7 \\
\hline & & 439,4 & 26,5 & 6,0 & 300,4 & 25,0 & 8,3 & 504,1 & 41,9 & 8,3 \\
\hline Inculta & & & & & & & & & & \\
\hline por improduc & & 506,9 & 79,5 & 15,7 & 495,2 & 86,2 & 17,4 & & & \\
\hline por desidia & & 176,5 & 1,0 & 0,6 & 168,4 & 0,7 & 0,4 & & & \\
\hline sin especificar & & 114,9 & & & 114,8 & 0,0 & 0,0 & & & \\
\hline & & 798,3 & 80,5 & 10,1 & 778,4 & 86,9 & 11,2 & $\emptyset$ & $\varnothing$ & $\varnothing$ \\
\hline Eras & & 73,0 & 3,0 & 4,1 & 8,9 & 0,5 & 5,6 & 16,7 & 0,9 & 5,6 \\
\hline $\begin{array}{l}\text { Tierras } \\
\text { desconocidas }\end{array}$ & & 54,3 & 20,0 & 36,8 & 50,5 & 25,5 & 50,6 & & & \\
\hline TOTAL & & $4.836,3$ & 532 & 11,0 & $5.282,41$ & $.130,6$ & 21,4 & $7.876,21$ & $1.969,2$ & 25,0 \\
\hline
\end{tabular}


Como decíamos, el monasterio sobre todo era propietario de tierra de sembradura, tanto regadía como secana. La mitad de la tierra de mejor calidad, la de huerta, era a mediados del siglo XVIII suya. En los Habares, a 50 pasos del casco urbano, poseía una heredad de 25 fanegas y 8 celemines, lindando con el río Cárdenas y junto a la los caminos de la Glera y el que iba a Baños de Río Tobía. En las tierras llamadas del Abad, junto al río molinar y la mojonera de Cárdenas y Badarán, disponía de 16 fanegas y 4 celemines, a un cuarto de legua. En la Sernilla, una heredad de 16 fanegas y 8 celemines, la mitad era regadía de la de mejor calidad, irrigada con la acequia que la rodeaba y junto a los ejidos de la villa. En Cascajos disponía de 9 heredades sueltas con 33 celemines, todas junto al río muelo. Al final de la Canal del Rojo, teniendo por cierzo el río molinar, poseía una heredad de fanega y media. Por último, de entre las de mejor calidad, falta por mencionar la de la Charca, a 20 pasos de la villa junto a la calle que baja del pueblo al río y de solo un celemín.

Las anteriores heredades y otras más en la M agdalena, la Charca y Adrillas, de segunda y tercera calidad, sumaban las 59 fanegas de las de mejor calidad destinadas al lino, cáñamo, habas, alubias, cebada en verde (alcacer), centeno para rotar la tierra y, en fin, los frutos de la huerta.

Como en Badarán, a pesar del abundante regadío, fundamentalmente la tierra era de secano de año y vez, salvo las 52 fanegas y 2 celemines de sembradura de secano cadañero en el pago que llaman de Santa Catalina, donde nada poseía el monasterio, el cenobio de San Millán era propietario de tierra secana que producía un año y descansaba otro. A mediados del siglo XVIII poseía 933 fanegas y 8 celemines de esta tierra ${ }^{40}$. Evidentemente sus heredades estaban repartidas por toda la jurisdicción de Badarán y en todos los pagos tenía una fuerte presencia, siendo las heredades del cenobio las que configuraban el espacio de cultivo. Las fincas del monasterio eran siempre las más grandes ${ }^{41}$ y no lo eran más porque en muchos casos no le interesaba: constantemente se describen las heredades dando como linderos otras suyas.

Las heredades muy grandes son inherentes al patrimonio de San Millán en Badarán. En 1597 se describe la "renta mayor" de la villa diciendo que contiene tres sernas de 74, 54 y 51 fanegas. La finca más grande del M onasterio de San Millán, y por tanto de Badarán, a mediados del siglo XVIII se componía de 81 fanegas, estaba situada en Los Almendros, a un octavo de legua. Era de sembradura de secano de año y vez, con 15 fanegas de primera clase, 25 de la de segunda y 41 de tercera. Aunque lindaba con otra finca de los monjes, éstos no hacían de esta heredad una finca de mayor extensión

40. En 1558 se arrendó la "renta mayor" de Badarán distinguiendo que 43 fanegas eran regadías cadañeras, y que las secanas de año y vez estaban en dos hojas, una de 302 fanegas y la otra de 205 fanegas y 8 celemines. Datos por gentileza de F. Brumont.

41. A mediados del siglo XVIII sólo eran de media más grandes las heredades del Concejo de la villa, pero se debía al caso de la heredad del Rincón de la G lera, de 54 fanegas, que luego se parcelaba entre los labradores. 
únicamente porque así quedaba mejor parcelada para redistribuirla entre los renteros. A esta finca le seguía en extensión la heredad situada en la Serna, de 56 fanegas y tres cuartas partes de un celemín, a 100 pasos de la villa, junto al camino de Nájera, un ribazo y una acequia. Era como la anterior, secana de año y vez, de la que 10 fanegas eran de primera clase, 25 de segunda y el resto de tercera.

De entre las 15 fincas más grandes del municipio, todas superiores a las 15 fanegas, 13 son del Monasterio de San Millán. No eran del cenobio la tercera, que pertenecía al Común de los vecinos y ocupaba 54 fanegas, y la última, de José Díez y Soto de 16 fanegas. Si a mediados del siglo XVIII las heredades de secano de año y vez de los monjes tenían una extensión media de 2,4 fanegas, las del resto de propietarios de tierra de Badarán eran de 1,1 fanega.

No todas las tierras del Monasterio de San Millán de la Cogolla estaban cultivadas. Una parte del terrazgo era tierra inculta. Los monjes también eran propietarios de tierra que por su naturaleza (orografía, humedad, cantos, etc.) era imposible de cultivar. A mediados del siglo XVIII eran de este tipo hasta 80 heredades que sumaban algo más de 86 fanegas de extensión. En este sentido destaca que el cenobio era propietario de tierra que podía ser cultivable y que se cultivaba y que, a diferencia de otros propietarios, ninguna de sus heredades quedaba sin ser sembrada por falta de rentero o por desidia.

De lo que no se podía librar el Monasterio de San Millán era de tener escrituradas tierras que aunque figuraban en los documentos (apeos, libros de administradores, compra-ventas, etc.) no aparecían en el campo. Eran tierras que no sabían si eran productivas, que desconocían sus linderos, su calidad, su estado, si las lleva en renta alguien... y que las dan por llecas porque de ellas sólo poseen el instrumento de pertenencia. El tiempo, los movimientos de mojones, las mejoras de las fincas, los cambios en las medidas de las tierras, la usura en el cobro de la renta (se pagaba tantas fanegas de grano por fanega de tierra), los arrendamientos de larga duración, la usurpación, la propiedad dudosa, el barbecho continuado, etc. habían provocado que en 1752 hasta 20 heredades con 25,5 fanegas de extensión estuviesen desaparecidas en la práctica. En el apeo de bayo de 1781 la extensión alcanzaba las 38,8 fanegas y en los apeos del padre Marcillach eran de 19,1 fanegas. En este sentido baste un ejemplo. Las 503 fanegas que eran propiedad del M onasterio de San Millán en la villa de Grañón se dieron en 1649 a renta a sus vecinos, éstos no conformes en la extensión de la tierra y, por tanto, de la renta cobrada, consiguieron después de varios y costosos pleitos que el corregidor de Santo Domingo procediese a un apeo en 1681: las tierras sólo medían 457,5 fanegas ${ }^{42}$.

42. Brumont, F., 1984, Campo y campesinos de Castilla la Vieja en Tiempos de Felipe II, Madrid, p. 7. 
Dejando de lado el tipo de tierra que poseía el Monasterio de San Millán en Badarán hemos de mencionar otra característica de su predio: todas las fincas estaban libres de cargas, circunstancia que las diferencia notablemente del resto de propietarios. Ninguna de sus heredades debe por misas, por aniversarios, por un censo impagado. El cenobio cuando adquiría una propiedad con la intención de mantenerla, satisfacía todos sus débitos y la dejaba libre de cualquier carga.

El Monasterio de San Millán se hizo con la tierra de Badarán a través de varios medios. El primero y más importante, gracias a los derechos y donaciones de reyes y gentes principales durante la Edad M edia. Sin lugar a dudas ese es el origen de su abultada hacienda en el municipio. Después le seguirían, en un orden de importancia diferente según la época histórica, la compra y las ejecuciones de sentencias, siendo la última razón la permuta.

La permuta sólo fue utilizada en casos puntuales, como en 1545, 1584 o $1640^{43}$. En el primer año el monasterio cambió todas las heredades de Villaporquera con un vecino del lugar por otras tantas y del mismo valor en el Valle de San Millán, Badarán y Cañas. Las permutas de 1577 y 1584 fueron mucho más interesantes y en ambas intervinieron el monasterio de Nuestra Señora de la Estrella de San Asensio y el de San Millán de la Cogolla. En el primer año La Estrella entregó a los benedictinos 21 fanegas y medio celemín por otras heredades cercanas a su casa. En 1584 el Monasterio de San Millán cambió sus 23 heredades con 92 fanegas y 9 celemines de tierra situada en San Asensio, Hormilleja y, sobre todo, Villarica, al monasterio jerónimo por 14 censos perpetuos situados en Badarán que rentaban 50 fanegas de trigo y 25 de cebada y que estaban fundados sobre 223 fanegas de sembradura y 87,5 obradas de viña ${ }^{44}$.

Hasta que el monasterio fue señor de Badarán empleó la ejecución de sentencias a su favor para adquirir heredades siempre que lo creyó conveniente. Puesto que el abad ejercía la justicia, tras sucesos graves, como los de 1561, el monasterio imponía multas que muchos encausados sólo podían saldar vendiendo propiedades (enseres, grano, inmuebles, tierras, etc.). En estos casos las almonedas obligadas rebajaban considerablemente los precios y el cenobio directamente 0 a través de testaferros podía hacerse fácilmente con aquellas heredades que le eran de su gusto. El monasterio también participaba en otras subastas. Los agricultores muy endeudados (por préstamos impagados, por la sucesión de varios años de malas cosechas, por demoras en satisfacer la renta, etc.) también se veían obligados a malvender sus haciendas. Bien conocidas son las críticas que se hacían desde la propia Iglesia sobre la posición de fuerza que empleaban muchas instituciones religiosas en las compraventas, sobrevalorando los precios para que nadie les hiciese competencia: "compran muchas

43. Sáenz Ruiz-O lalde, J.L., 1992, pp. 34 y 36.

44. AHN, Códices, 1034b, ff 29 y 352. Clero, leg. 3067. 
veces por precio tan crecido que excede de lo justo. $Y$ si en las almonedas y subastación se las compiten, suelen subir a tanto que doblan el precio de su valor, sin que ningún secular o persona particular se las pueda competir por el conocido exceso de dinero en que las ponen. En lo cual nunca van a perder, porque comprando la heredad se arrogan juntamente el diezmo de ella, en que tiene mucha utilidad, así por calidad, como por la seguridad de la renta y tenues gastos en su cobranza. Todo lo cual intentan, consiguen y defienden con privilegios mal entendidos y siniestramente interpretados y con costumbres, que verdaderamente son corruptelas; de lo cual se siguen a la República, en lo eclesiástico y secular, gravísimos daños"45.

El monasterio también utilizó la compra para adquirir tierra en Badarán durante la Edad Moderna. Evidentemente, como ya disponía de la mayor hacienda del municipio, durante esta época lo hizo de forma selectiva, principalmente para redondear sus heredades, buscando las de mejor calidad, las más cercanas, las regadías sobre las secanas y para adentrarse en aquellos pagos y nuevas tierras puestas en cultivo. Entre 1499 y 1710 se tiene constancia de que el monasterio llevó a cabo hasta 15 operaciones de compra consistentes en 23 fanegas y 3 celemines de sembradura y 4 obrada de viña por un valor de 61.492 maravedís. Del legado del cardenal Sáenz de Aguirre, el monasterio invirtió en Badarán de forma testimonial para adquirir 7 fanegas de tierra, 11 celemines, 1 cuartillo y 52 varas $^{46}$.

Tras los procesos de ventas públicas y compras también se escondían intenciones ajenas a la simple adquisición de patrimonio. Los monjes utilizaban estos sistemas como armas que anulasen a sus contrincantes. Los vecinos insatisfechos con el monasterio, aquellos que destacaban por encabezar algaradas, los que arremetían contra sus derechos en el concejo o en la construcción de molinos, eran acorralados a través de la propiedad de la tierra, primero impidiendo el acceso al arrendamiento de heredades del cenobio, lo que les obligaba a buscar nuevas tierras, y saliendo al paso en las compras para adquirir aquellas heredades en las que estuviesen interesados los adversarios. En las sesiones monasteriales de 22 de septiembre de 1631 y 2 de mayo de 1632 se dirá que era conveniente comprar la heredad de tres fanegas y cinco celemines que está junto al "primer molino" propiedad del cenobio para "adelantar la renta del dicho molino, para cobrar del dueño de ella cierta cantidad de dinero que debe" y para evitar que la adquiera "un hombre poco afecto a esta Casa"47.

45. Constituciones Sinodales antiguas y modernas del Obispado de Calahorra y la Calzada. Reconocidas, reformadas y aumentadas novisimamente por el Ilustrísimo Señor Don Pedro de Lepe, O bispo de este O bispado, del Consejo de su Majestad. En el Sínodo diocesano que celebró en esta ciudad de Logroño en el año de mil y seiscientas y noventa y ocho. Madrid, Antonio González de Reyes, 1700, pp. 479-481.

46. Sáenz Ruiz-O lalde, J.L., 1992, pp. 27 y 31.

47. AH N, Clero, libro 6086, ff. 95v-108v. 
Con el objeto de mantener lo más íntegra la hacienda de Badarán, el Monasterio de San Millán llevó a cabo diversos apeos de las heredades y el abad y sus vicarios reiteradamente mandaron a los monjes administradores que la vigilasen con celo y atención. De entre los numerosos apeos destacan los de 1534, 1597, el confeccionado por Bayo en 1781 y las informaciones del padre Marcillach de 1821. Pero hay muchos más de menor entidad. Hemos de tener en cuenta también que el administrador anotaba en pliegos de papel todas las cuentas e incidencias de la hacienda de Badarán; pliegos que luego conformaban los llamados Libros de gobierno de los bienes de la villa. El administrador debía dar cumplida cuenta de todas las incidencias de la hacienda de Badarán a la casa matriz y al sucesor en su cargo.

El sistema que utilizó el M onasterio de San Millán para explotar la hacienda de Badarán durante la Edad Moderna fue el arrendamiento. Aunque un elevado número de las viñas de otras villas, como Cárdenas y Cordovín, fueron administradas directamente, de las de Badarán sólo se conocen arrendamientos. El monje administrador de los bienes del cenobio podía retener para su cultivo directo algunas pequeñas porciones de huerta para consumo de hortaliza y legumbre, pero no hay constancia de que llevase directamente a través de operarios tierra alguna de forma continuada.

El monasterio consideraba toda la hacienda de Badarán como una única - la dividía en dos, tres, cuatro o más partes, en estos casos, hablaba de la "renta mayor" o "la mayor", y un segundo nombre referido generalmente al pago donde se localizaba el grueso de la otra hacienda o el nombre del rentero: "La Isla", "Viavacas", "El Rojo", "Sobrevilla", "Diego Vergara", "la renta de Sancho Lacayo", etc. Naturalmente, la "renta mayor" se componía del grueso de la hacienda, entre el 70 y el $90 \%$ de toda la tierra que poseía en Badarán: en el año 1534 esta renta era de 611 fanegas, 4 celemines y 264 obradas, en el año 1597 se componía de 541 fanegas, 8 celemines y 260 obradas; la renta de "Sobrevilla" se componía en el año de 1597 de 72 fanegas y 116 obradas, la de "Sancho Lacayo" de 34,5 fanegas de tierra, etc.

El conjunto de heredades dadas a renta se dividía en lotes. El número de éstos era variable, en unas ocasiones fueron 18 en otros 44 . Como en el resto de la hacienda emilianense, en Badarán se procuraba concertar la escritura de arriendo ante el escribano, con los vecinos en particular y con el Concejo y Regimiento de la villa. De la escritura de arrendamiento se hacían dos copias, una se depositaba en el archivo de la abadía y la otra quedaba en poder del administrador local. El monasterio podía llevar a cabo el arrendamiento con un particular o grupo de ellos o formalizarlo con el Concejo de la villa. La segunda opción fue la que se aplicó en casi todas las ocasiones: el Común de la villa se hacía cargo de la renta, siendo el único responsable de satisfacerla al monasterio. El Concejo se encargaba posteriormente de repartir las heredades entre los vecinos del pueblo así como de fijar la cuantía de las rentas de cada individuo dentro de cada lote. En determinadas circunstancias, el monasterio podía imponer como condición para asegurar el cobro de la renta la hipoteca de bienes del municipio o de particulares. 
Próxima la fecha de arrendar la hacienda emilianense, se anunciaba en la misa dominical y se indicaba las fechas de las subastas. La información se completaba con carteles anunciadores en la puerta de la parroquia. Los candidatos se presentaban delante del notario o de la autoridad convenida y hacían su oferta o postura delante de testigos. El que más pujaba obtenía el contrato al tiempo del remate, o momento fijado de antemano como final de la subasta. El monasterio podía reservarse el derecho de permitir la puja del cuarto, es decir, la oferta mejorada en un cuarto de un candidato que no había logrado lote alguno. Lo cierto es que el sistema de pujas sólo se utilizó de forma frecuente en momentos muy determinados y siempre con lotes de tierras limitados en épocas de bonanza económica. Lo más usual en Badarán durante la Edad Moderna fue un acuerdo entre el Concejo de la villa o un conjunto de vecinos y el monasterio, variando mínimamente la renta de años anteriores.

El Monasterio de San Millán no mantuvo una postura única sobre los poderes que tenían los administradores de sus haciendas y sobre cómo se debía proceder en la formalización de los arrendamientos. Este hecho provocó que en algunas ocasiones bastase con que los vecinos de Badarán formalizasen el arrendamiento en casa del administrador, sólo ante él o acompañado del monje ecónomo u otros, y en otras ocasiones tuvieron que desplazarse hasta San Millán para poder formalizarlo ante el notario y el abad. Esta segunda situación era muy perjudicial tanto para el cenobio como para los arrendatarios, máxime cuando hubo más de una ocasión en la que tras la molestia de desplazarse hasta la casa matriz, ni el escribano ni el padre abad se encontraban allí y o había que retornar a Badarán sin escritura alguna o se tenía que permanecer en San Millán a la espera de los firmantes ${ }^{48}$. No cabe duda de que estas molestias no beneficiaban a nadie, el arrendamiento podía no celebrarse por cuestiones engorrosas y ajenas a la formalización del contrato.

El tiempo por el que se hacía el arriendo no fue siempre el mismo. Los arrendamientos más frecuentes duraron 9 años, seguidos muy de cerca por los de 8 , pero también los hubo de 5 , de 6 y de 25 años e incluso alguno se formalizó por la vida de un rey y otros de forma perpetua. En todos los casos el monasterio prohibía el subarriendo y si se producía el rentero era despojado de las tierras. Los arrendamientos perpetuos sólo aparecen en la primera mitad del siglo XVI y tendieron a desaparecer tanto por la mínima cuantía que rentaban al monasterio como por que podían derivar en la pérdida de la propiedad plena de la tierra del cenobio. Los que abarcaban varias vidas de reyes, arrendamientos a muy largo plazo, se formalizaron en unas pocas ocasiones durante el quinientos y seiscientos, en momentos en lo que el monasterio desea estabilidad o se veía avocado a dejar la tierra lleca. Según nos aproximamos a 1800 se repiten con más insistencia los contratos por 9 años, sólo salteados por los

48. Sáenz Ruiz-O lalde, J.L., 1992, p. 240. 
de otra duración tras determinadas circunstancias. Los arrendamientos de 8 y 9 años se adaptaban muy bien al barbecho, en Badarán casi todas las tierras eran de año y vez, y además eran lo suficientemente largos para impedir una explotación desmesurada de la tierra en detrimento de su calidad y lo eficazmente cortos como para permitir la renovación de los colonos y adaptar la renta a las coyunturas económicas.

Sobre las tierras dadas a censo perpetuo nos encontramos con que a mediados del siglo XVIII había 14 personas (16 escrituras) con tierra en Badarán que manifiestan que todas 0 algunas de sus heredades tenían cargas perpetuas a favor del Monasterio de San Millán. Estas cargas eran pequeñas cantidades de trigo y cebada y que en alguna ocasión incluían el pago de una gallina o porción de ella. Casi seguro que la mayor parte de estos pagos son viejos arrendamientos perpetuos dados por el monasterio a diversos colonos y herencia de las permutas realizadas con el monasterio de la Estrella en 1577 y 1584. En total, el número de heredades con cargas de este tipo eran hacia el año 1750 de 163 con una extensión de 138,5 fanegas de cabida. Según Bayo en 1781 había en Badarán 17 censos con 295 heredades y 321,3 fanegas, cifra excesiva que seguro incluye censos redimibles que nada tiene que ver con los que aquí nos ocupa. Más plausibles son los números facilitados por los expedientes de enajenación de 1821 donde se habla de 10 lotes de tierra con censos perpetuos con una extensión de 162,2 fanegas, cifras que se repiten en el Libro de gobierno de Badarán del padre Marcillach en 1824 (la extensión ahora es de 162,6 fanegas). Sea la cantidad que sea, lo cierto es que el Monasterio de San Millán ya consideraba a finales del siglo XVIII perdida la propiedad de la tierra dada a censo perpetuo aunque seguía tomando al detalle nota de las heredades, extensión localización y tenedor.

Por otro lado, el monasterio permitió en muchas ocasiones que el contrato de arrendamiento no quedase roto por fallecimiento de los renteros si cumplían con las mismas obligaciones sus herederos. Incluso no vio mal que terceras personas vinculadas con el fallecido familiarmente (yernos por ejemplo) o por oficio (labradores con los que llevaba este u otros arrendamientos) lo continuasen en igualdad de circunstancias. En todos estos casos era necesario un informe, verbal casi siempre, favorable del administrador local de la hacienda monasterial. Sólo cuando se incumplía de forma descarada con las condiciones del arrendamiento se privaba al rentero de las tierras. Eso sí, si el administrador observaba conductas poco edificantes hacia el monasterio 0 una explotación inadecuada de las heredades, vetaba al colono en el próximo arrendamiento.

La renta se pagaba en casi todos los casos en grano, trigo y cebada. En muy pocos arrendamientos se entregaba dinero; si se hacía era por la renta de viñas, pero en Badarán las viñas se incluían en los lotes de la tierra blanca y huerta así que el canon era grano. Los arrendamientos específicos de viñas, poco frecuentes en Badarán como decimos, pero numerosos en Cordovín y Cárdenas, especificaban una duración más larga, preferentemente 80 años e incluía condiciones sobre su laboreo así como referentes al descepe. 
Normalmente el inicio del arrendamiento comenzaba con el arrancado de las cepas, el monasterio solía financiar al colono y postergaba el cobro de rentas para cuando la vid comenzase a dar fruto. La larga duración del arrendamiento permitía la confianza del rentero en la heredad y su constante mejora, evitando la sobreexplotación, a la vez que finiquitaba con la vejez de la viña.

Durante el siglo XVI los cobros de las rentas solían incluir una gallina o un capón, como clara reminiscencia feudal, pero esta práctica se perdió y sólo se mantuvo en los arrendamientos perpetuos. Todas las tierras del monasterio estaban dadas a renta a mediados del siglo XVIII a 63 individuos: 45 de vecinos de Badarán, 13 de Cordovín, 4 de Cárdenas y 1 de Estollo. De todos los arrendamientos 59 se pagaban en especie, por los otros 3 no se entregaba cantidad alguna. Sólo un vecino de Badarán satisfacía la renta en trigo, el resto entregaban pan mixto, mitad trigo y mitad cebada normalmente, aunque también otras proporciones. El arrendatario tenía obligación de pagar puntualmente la renta independientemente del "riesgo y ventura que corriese", debía cultivar la tierra con todas las labores "conforme se hacía en le país" manteniendo la calidad e integridad de la heredad, no podía subarrendada y si, tras el tiempo estipulado, deseaba continuar con el arriendo, debía formalizar nuevo contrato.

Con el objeto de facilitar el arrendamiento, encontrar mejores postores y mitigar el efecto de la renta, el monasterio frecuentemente incluyó en la renta el diezmo, de manera que se daban las tierras monasteriales en arriendo diciendo que esa tierra estaba exenta de pagar el diezmo o apostillando que su cuantía ya iba incluida en la renta. Esta costumbre, aunque muy utilizada por este y otros monasterios, no era conforme a las disposiciones decimales generales (su uso se abolió por bula papal en 1796) porque conducía a la ocultación del diezmo, al impago a sus legítimos propietarios y a una competencia desleal en el arrendamiento de las tierras de los conventos y monasterios con el resto de instituciones eclesiásticas y del común. La inclusión explícita del diezmo en la renta la encontramos con frecuencia en el siglo XVI y casi nunca en otros siglos, pero existen más que indicios para pensar que se siguió con la práctica aunque de forma soterrada, y es que el diezmo utilizado de esta forma hacía las heredades un diez por ciento más valiosas, como decían los contemporáneos, a lo que debemos añadir que también beneficiaba a los colonos al reducir algo la tasa de la renta. 
Renta de trigo y cebada que recibe el Monasterio de San Millán de la Cogolla por el arrendamiento de sus tierras en Badarán ${ }^{49}$.

\begin{tabular}{|l|c|c|c|}
\hline Año & Fanegas de trigo & Fanegas de cebada & Total fanegas \\
\hline 1516 & 295 & 295 & 590 \\
\hline 1685 & 370 & 280,8 & 650,8 \\
\hline 1691 & 376,7 & 263 & 639,7 \\
\hline 1752 & 267,7 & 259 & 526,7 \\
\hline 1771 & 391,8 & 383,3 & 775,1 \\
\hline
\end{tabular}

Como bien se conoce ya ${ }^{50}$, el Monasterio de San Millán recibió por el arrendamiento de sus tierras en Badarán un número casi siempre mayor de trigo y cebada: 590 fanegas de pan mixto en el año 1516, 650,8 en 1685, 775,1 en 1771, etc. Pero este aumento sólo se debía al creciente número de heredades que el cenobio iba incorporando a su predio. Realmente la renta, fanegas de grano por fanegas de tierra arrendada que se pagaba por la tierra del Monasterio de San Millán en el Valle del Cárdenas, y en Badarán de forma especial, creció a lo largo del siglo XVI y cayó de forma espectacular a partir de 1580. El monasterio dejó de percibir importantes cantidades de grano por el arrendamiento de sus tierras y aunque levemente fue mejorando en la segunda mitad del siglo XVII la situación no fue muy prometedora; en las primeras décadas del XVIII la renta se estancó e incluso retrocedió, sólo en la segunda mitad del siglo XVIII la situación es arrendamiento tras arrendamiento más favorable para las arcas del Monasterio de San Millán de la Cogolla. A mediados del siglo XVIII el valor de las rentas de trigo y cebada que el monasterio cobró por sus tierras en Badarán alcanzaron los 216.067 maravedís a precios corrientes (la utilidad de la tierra se estimó entonces en 736.133 maravedís).

En algunas ocasiones el Monasterio de San Millán fijó tasas de renta para Badarán, esto es, estableció qué cantidad de grano debía entregarse por cada fanega de tierra puesta en arriendo. Según sus peritos en 1578 la calidad de la tierra de la "renta mayor" (577 fanegas) debía hacerse por 6,5 celemines mitad trigo y mitad cebada por cada fanega de superficie (lo que nos da un total de 312,5 fanegas de pan mixto para toda la renta). Tasada la renta o no lo cierto es que en la práctica el monasterio cobró de media por la "renta mayor de

49. El año de 1516 incluye el diezmo, según Brumont, F., 1980, «La rente de la terre en Rioja occidentale a l'epoque moderne», M elanges de la Casa de Velázquez 16, p. 264. El año de 1752 según las respuestas particulares del Catastro de Ensenada. Los años 1685, 1691 y 1771 según Sáenz Ruiz-O lalde, J.L., 1992, p. 73.

50. Brumont, F., 1980, «La rente de la terre en Rioja occidentale a l'epoque moderne», Melanges de la Casa de Velázquez 16, pp. 237-272. 
Badarán" en 1531 una renta de 6,2 celemines de pan mixto por fanega de tierra, en 1558 fue de 6,6 celemines, en 1583 de 5,6 celemines, en 1752 de 5,7 celemines y en 1781 de 8,2 celemines, en estos dos últimos años entendiendo que era de toda la tierra que el monasterio poseía en la villa. La tasa de la "renta mayor" puede compararse con la de otras tierras del propio Badarán. Las 44 fanegas de tierra de Viavacas estaban tasadas en el año 1554 en 8,2 celemines de pan mixto por fanega de superficie; a las tierras conocidas como "Valvanera", con una extensión de 107 fanegas en 1586, se les estimó una tasa de 6,3 celemines por fanega de tierra.

En 1758 el Monasterio de San Millán definió para el conjunto de su hacienda y para Badarán cinco tipos de tierra y especificó cuánto se debía cobrar de renta por cada fanega de tierra. La 1ạ era la regadía cadañera destinada al cultivo de cáñamo, su renta debía ser de 17 celemines de pan mixto por fanega. La 2a comprendía la tierra cadañera de secano de primera calidad que se sembraba todos los años de cebada, la renta de esta tierra era de 16 celemines por fanega. La 3a era la tierra secana de año y vez de primera calidad que producía un año trigo y descansaba el siguiente, volvía a sembrarse cebada y tras otro descanso producía centeno; su renta 15 celemines por fanega. La 4ạ era la tierra secana de año y vez de segunda calidad que se sembraba y producía como la anterior, su renta 14 celemines por fanega. Y la 5a era la tierra de secano de tercera calidad con siembra y cultivos como la anterior por la que debía pedirse una renta de 12 celemines por fanega ${ }^{51}$.

El monasterio sólo pudo aplicar estas tasas en periodos de bonanza económica y cuando el número de renteros que pujaban por sus fincas eran suficientes, pero estas circunstancias sólo sucedieron en un número reducido de veces. Es más, la abultada concentración de tierras en determinadas localidades, como en el caso de Badarán, provocaba que la mayor parte de las veces sólo se presentasen a los arrendamientos los vecinos de la villa, quienes procuraban no elevar la tasa de la renta. En una jurisdicción tan grande y con tan elevado número de heredades como Badarán, no es extraño que aparezcan renteros de las localidades limítrofes (Cordovín, Cárdenas, Villaverde) para llevar las tierras que lindaban con sus jurisdicciones 0 , como en el caso de las viñas, porque el cenobio confiaba más en la maestría de la cultura de los de Cordovín. Si el arrendamiento recaía en manos de un vecino de un municipio alejado, el colono se veía obligado a desplazarse con su familia y enseres hasta Badarán, lo que le ocasionaba no pocos problemas además de la potencial enemistad con los lugareños por haberse hecho con rentas que creían suyas.

Las más de las veces el Monasterio de San Millán tuvo que ayudar a los colonos para incentivarles a tomar en renta las tierras del cenobio $y$, una vez logrado, para que pudiesen disponer de grano para la siembra, dispusieran de dinero para emprender mejoras en las heredades o en los aperos de

51. A partir de Sáenz Ruiz-O lalde, J.L., 1992, p. 315. 
labranza e incluso ser benigno con el cobro de las rentas. Muy a su pesar el monasterio, siempre expresando mucha reticencia y hablando de excepcionalidad, debía ser condescendiente con sus renteros porque podían acabar siendo tan pobres que no le sirviesen ni como pecheros 0 , peor aún, mudasen de villa. A los vecinos de Badarán les entregó el cenobio "los granos necesarios" par la siembra en 1758 después de varias malas cosechas porque, además de caridad, "es interés del monasterio, por interesar en esto las rentas y diezmos"52. En 1801, tras una grave crisis agraria, los monjes ofrecieron grano a los de Badarán "para su socorro". También fueron frecuentes los pequeños préstamos en dinero a los nuevos colonos al comienzo de los arrendamientos para que llevasen a cabo mejoras en las fincas 0 en sus utensilios de labranza. Al final, si nadie deseaba tomar a renta las heredades monasteriales los monjes amenazaban con labrarlas ellos directamente, y en ocasiones lo cumplieron, pero era tan enojoso para el monasterio que preferían una renta baja. Y los colonos, sabedores de que con tan sólo sus haciendas no tenían para sobrevivir, buscaban convenir un contrato con el abad, aunque no fuese tan provechoso como anhelaban.

En 1738 las solicitudes de los arrendatarios de Badarán no fueron escuchadas, así que al finiquitar el arrendamiento nadie tomó rentas del M onasterio de San Millán y el cenobio tuvo que improvisar la administración de toda su hacienda con un laico al que vistieron de lego. Tras varios años estériles y de corta cosecha, los renteros solicitaron una rebaja en las cantidades convenidas en la renta: "propuso en consejo el padre abad cómo los renteros en la renta mayor de Badarán se resistían hasta el día de hoy a tomar dicha renta por el motivo de hallarse muy atrasados de medio a causa de los dos años precedentes que fueron muy estériles y desgraciados, diciendo que les era imposible labrar las tierras por no tener qué comer ni con qué alimentar a los ganados. Y en vista de estas miserias, su paternidad, por pura compasión y misericordia, les había ofrecido precisamente sesenta fanegas de trigo para que se remediases, sin obligación de pagarlas, o que de cada fanega de la renta de este año se les dejaran dos celemines graciosamente para su alivio". También les ofreció grano para la siembra. Pero a los vecinos les pareció insuficiente y abusivo tal como corrían los tiempos. Querían una rebaja adecuada en la renta de todos los años, la sexta parte, y no sólo para el primer pago. "Y presumiendo su paternidad de tanta y tan común resistencia haber algún monipodio secreto y considerando el daño gravísimo que a esta Casa se sigue de hacer la pretendida rebaja en este lugar, y porque a su imitación y ejemplo pretenderán otro tanto los renteros de este Valle y otros lugares, después de haber oído los dictámenes y razones que propuso cada uno de los del consejo, se resolvió uniformemente que esta Casa se esfuerce a labrar la porción de tierra que los renteros no quisieren tomar o la parte que pudiere labrar". En el consejo monasterial de 26 de junio de 1739 se resolvió

52. AHN, Clero, libro 6085b. 
"buscar persona hábil, robusta y experimentada en la labor de tierras" para llevar las tierras de Badarán, esta persona era Francisco Bujanda, natural de Baños de Ebro, quien ya había llevado las heredades del monasterio en esa tierra. Para que no existiese resquicio de ilegalidad se acordó darle "el hábito de religioso lego".

Como hemos visto, el Monasterio de San Millán de la Cogolla ejercía en Badarán un domino económico total 0 , si se prefiere, próximo al completo control de las actividades económicas de la villa. La propiedad de inmuebles, la titularidad de los diezmos, el cobro de impuestos, el préstamo de dinero y, sobre todo, la posesión de tierra, hacían del monasterio al mayor propietario y sin competencia posible. Las rentas que obtenía el monasterio de Badarán, que variaron con el tiempo en composición y proporción, siempre fueron en aumento. Sirvan los datos adjuntos como ejemplo.

Ingresos en trigo y cebada de la administración de Badarán procedentes de todo tipo de rentas (diezmo y renta de la tierra sobre todo) ${ }^{53}$

\begin{tabular}{|l|c|c|c|c|}
\hline Año & Trigo, fanegas & Cebada, fanegas & Total fanegas & Índice \\
\hline 1685 & 441 & 352 & 793 & 100 \\
\hline 1691 & 447 & 334 & 781 & 98,5 \\
\hline 1771 & 499 & 383 & 882 & 111,2 \\
\hline 1816 & 1.066 & 452 & 1.518 & 191,4 \\
\hline 1833 & 1.105 & 656 & 1.761 & 222,1 \\
\hline
\end{tabular}

\section{Administración de los bienes y derechos.}

Los bienes y derechos que el Monasterio de San Millán de la Cogolla tenía en Badarán se custodiaban por medio de un administrador. Éste vivía en la casa monasterial asistido por una criada y un criado menor. Para los asuntos del campo, diezmos, tributos y rentas tenía potestad de contratar a los operarios que le fuesen convenientes. La administración de Badarán era una de las diez que el Monasterio de San Millán de la Cogolla mantuvo durante la Edad Moderna; en cuanto a cuantía, ocupaba la cuarta posición por el número de ingresos que proporcionaba al cenobio. Una peculiaridad de la administración de Badarán es que sólo tenía obligación de recoger las rentas de la propia villa, circunstancia que también se dio en la de Cordovín y en la de Cárdenas. Excepcionalmente se administró desde Badarán los bienes de Alesanco, Alesón y Bobadilla.

53. AHN, Clero, libros 6078 y 6054; legajo 3103. En Sáenz Ruiz-O lalde, J.L., 1992 p. 461. 
Como monje, el administrador debía cumplir con to da una serie de obligaciones religiosas y de observancia de la orden de San Benito, como administrador sus labores se reducían al cobro de rentas y tributos, a la compraventa de los bienes y tierras y a la escrituración de los arriendos. En este último caso, asistido por el padre granero del monasterio u otros monjes. El monje administrador no desempeña ninguna función en el municipio, tan sólo y en fechas señaladas hacía de confesor; no ejercer oficio alguno llegó a "repugnar" a algún abad y fue motivo de su traslado a la granja de San Martín de Soto, como ocurrió entre 1798 y 1801. El padre administrador, como vemos, sólo tutelaba y salvaguardaba los bienes y derechos del cenobio en la villa. Todo la vida económica que generaba debía anotarla en los libros de gobierno. D ebía entregar cuentas al monasterio dos veces al año, en San Juan y Navidad, y al entrar y salir del oficio, un memorial jurado.

El administrador de los bienes de San Millán acostumbraba a ocupar su cargo durante 4 años, pero con frecuencia repetía en el puesto. Incluso en ocasiones la administración se dilató en exceso, como la de Plácido Díaz quien estuvo en Badarán desde 1785 hasta 1801. El administrador recibía como sustento una parte de los ingresos que recaudaba; al final del siglo XVIII el salario quedó fijado para todas las administraciones de San Millán de la Cogolla en 35 fanegas de trigo, 60 cántaras de vino y 4.400 reales.

Si el administrador vivía permanentemente en Badarán era porque el voIumen de las rentas que aquí se obtenían era considerable. Además la casa monasterial de la villa tenía otra función, la de hospedería para los monjes y servidores del monasterio en tránsito. Aunque la casa matriz siempre manifestó su disgusto por el abuso que se hacía no sólo socorriendo a los monjes y personal de San Millán sino admitiendo como huésped a personas ajenas a la orden, a las casas de Badarán, Cihuri y San Miguel de Pedroso, se les consideró de mayor categoría y por ello sus administradores recibían 840 reales y 70 fanegas de cebada para atender las necesidades de comidas, cenas, camas y animales.

Aunque el administrador conventual residía siempre en Badarán, en algunos años el abad de San Millán consideró innecesaria su presencia en la villa. Entonces o permanecía en San Millán o, más frecuentemente, en la granja de San Martín de Soto. Pero al poco de marchar de Badarán, volvía, como tras su partida en 1737 y su vuelta en 1741, porque su ausencia siempre era origen de daños contra la hacienda del monasterio: Ios vecinos entregaban granos de peor calidad, se hacían sacas en las cosechas antes de cobrar el diezmo, era imposible llevar una contabilidad adecuada de los diezmos menudos, los enseres de la casa, bodega y hórreo decimal se malograban, en unas ocasiones los ratones se comían los colchones, en otras las lluvias rompían los tejados, y, lo peor, el grano y vino que allí se almacenaba no estaba convenientemente atendido y custodiado. Todo ello sin contar con que el administrador sólo permaneciendo en Badarán podía estar al tanto de las ratificaciones de los censos y rentas a favor del monasterio tras el fallecimiento de los deudores y arrendatarios, así como comprobar que ningún vecino se hiciese con bienes del cenobio. 
El administrador debía conocer a los vecinos de Badarán que mantenían relaciones económicas con el monasterio. Saber de su hacienda, de su conducta, de su honradez... tarea en la que era ayudado por los clérigos de la parroquia. Este tipo de información le resultaba muy valiosa al cenobio para otorgar o no préstamos y para ofrecer tal o cual arrendamiento a esta 0 aquella persona, en especial tras sucesos violentos con el monasterio o cuando algunos llevaban a pleitos a los monjes. Por otro lado, también ocurría que cuando un administrador permanecía mucho tiempo en la villa intimaba con determinados vecinos y procedía, contrariamente a sus obligaciones, a fiarles grano 0 a dejarles hacer uso de tierras o bienes del monasterio.

Aunque siempre se procuró administradores hábiles e inteligentes para que con el trabajo diario y continuo venciesen las dificultades que se les planteasen, su designación dependía del abad y éste no tenía porqué poner a personas doctas en la materia y sí a individuos de su devoción y a quienes debiese favores. Así ocurrió en los abadiatos de los padres Plácido Véa (17051709) y Lorenzo Muro (1709-1713 y 1717-1721). Evidentemente de tales hechos resultaban graves perjuicios para la hacienda emilianense, siendo necesarios muchos esfuerzos y gastos por parte del cenobio para poder recuperar lo perdido. Par evitar nombramientos inadecuados se crearon juntas monasteriales para valorar las designaciones y se limitaron las funciones del administrador, pero era inútil, tras el abad que así procedía siempre sucedía otro que echaba por tierra los avances conseguidos.

Este tipo de situaciones son las que motivaron a Mauro Marcillach a compilar todo tipo de avisos y reglas de cómo administrar la hacienda de Badarán. Se entienden mejor las palabras de M auro si comprendemos que escribe tras el Trienio Liberal: que los administradores lean estas normas "y que no anden a ciegas y tengan que informarse de extraños, que, aunque se vendan por muy afectos, tal vez no les dirán la verdad más que al gusto de su paladar"54. Así instará a que no se de ni grano ni dinero a fiar a nadie porque "todos son hombres muy de bien y tienen sus casas muy abastecidas cuando vienen a pedir, y después nunca les falta un achaque para no pagar o ir dilatando la paga; y si esta se ha verificado en todo los tiempos, mucho más en los presentes [1824], en que los granos, cáñamo, lana y todo valen tan barato y la moneda anda tan escasa que casi por necesidad tienen que ser tramposos, ni se halla un cuarto en las personas ni tienen de qué hacerlo, ni apenas les llega cuando venden para pagar las contribuciones" 55 .

El padre Marcillach, bien sabedor de que los derechos y rentas tradicionales de la Iglesia estaban en peligro tras los aires reformadores de la Revolución Francesa, la Guerra de la Independencia y la llegada de los liberales al poder, ponía énfasis en que todo estuviese por escrito, hasta al mí-

54. Sáenz Ruiz-O lalde, J.L., 1992, p. 280.

55. Archivo de San Millán de la Cogolla, Libro de gobierno de Badarán, f. 229. 
nimo contrato o préstamo y que fuese con firma del abad, que los únicos préstamos fuesen en grano, porque así se podría recuperar con la cosecha venidera. El cobro de rentas debía hacerse en las eras conforme los arrendatarios trillaban su grano, llevando el administrador las medidas, la fanega, el celemín y el rasero, no fiándose de otros instrumentos. El administrador debía estar presente en el cobro de la renta y los de Badarán ya se encargarían tras la merienda llevar el grano con sus caballerías a los almacenes del monasterio. Como el administrador tenía la obligación de estar cobrando las rentas en las eras, era necesario poner a una persona de mucha confianza en el almacén para comprobar que los parroquianos entregaban el grano. De ningún modo se debía permitir depositar como renta, tributo o diezmo grano mojado, sucio y de mala calidad.

Marcillach también elaboró un decálogo sobre la cobranza de los diezmos, indicando qué clase se recogían en la villa y cómo había que proceder con cada fruto. Más interesente es cómo el administrador debe preparar la bodega monasterial para recibir la uva. Se han de limpiar los tinos y las cubas, se ha de disponer de una comporta para que los vecinos depositen la décima. Luego debía encargarse de velar porque el pisado y el posterior transporte del orujo al trujal se hiciesen con corrección. Finalmente se debían llenar las cubas que el monasterio tenía en la bodega, comprando el vino necesario para rellenarlas.

El monje también nos habla de algunos pormenores sobre la conservación de la hacienda monasterial. Los vecinos habían convertido en una pantanal la finca de la Magdalena, de 30 fanegas de cabida, al abrir una cava para traer agua del río Cárdenas y poder regar los huertos y cáñamos. Aunque les había dado permiso, hicieron una zanja y no una acequia, y el agua la rompía por todas partes, dejando el camino intransitable y la heredad casi inutilizada. Marcillach conminaba a su sucesor a que no les dejase de nuevo llevar a cabo la obra y que si se oponían, no dudase en sacar Provisión de la Chancillería de Valladolid.

Aunque sin llegar tan lejos, también pedía Marcillach compensación económica por los abusos en el cerrado de Balza. Como entre 1820 y 1823 la hacienda monasterial había estado abandonada "sin dueño" y sin que nadie "Io estorbara", Ios vecinos de Badarán habían utilizado el cerrado a sacar tierra para tejas y otros usos: "para cualquier cosa que se les ofrezca, ya para terraplenar sus eras, ya para hacer barro, a Sombillo a sacar tierra". Si seguían así, la heredad quedaría inutilizada por lo que será necesario que la villa "nos pague el daño que nos causan o que nos den en otra parte igual porción de terreno y de la misma calidad". 


\section{Conclusión.}

Badarán ejemplariza el dominio de un señorío abacial durante la Edad Moderna. Fue durante la Edad Media uno de los más importantes pilares del dominio del Monasterio de San Millán de la Cogolla y lo seguirá siendo, quizá más, durante la Edad Moderna. Aún importantes, el señorío y los derechos señoriales pasan en esta época a un segundo plano, siempre latentes para manifestar un dominio pleno antiguo, pero siempre tras el control económico. Jurisdicción y exacción económica redondeada y fortalecida con el dominio eclesiástico. El abad es vere nullius dioecesis y se impone en el nombramiento de los servidores de la parroquia y su sustento a la par que en la conducta religiosa de los parroquianos a través de las visitas abaciales. No importa que Badarán lograse hacerse con el señorío décadas después de que Felipe II obligase al monasterio a desprenderselo, sin él es igualmente capaz de mantener cargas señoriales con claras reminiscencias señoriales hasta la llegada del Estado Liberal. Su poder era manifiesto en el terreno económico: diezmos, préstamos, inmuebles y, fundamentalmente, tierra son sus pilares, y hacen del monasterio el primer y más destacado propietario en la villa y le confiere un poder a la casa matriz que trasfiere el ámbito local. No sólo es popietario sin más, lo es de lo mejor. Posee uno de los más preciados bienes de un mundo agrícola, los únicos molinos harineros de la villa, a la par que dispone de casi toda la tierra de la mejor calidad. Los vecinos de Badarán fueron durante la Edad Moderna mitad vasallos, mitad renteros, mitad feligreses del Monasterio de San Millán de la Cogolla. 
